\title{
Role of Postbiotics in Diabetes Mellitus: Current Knowledge and Future Perspectives
}

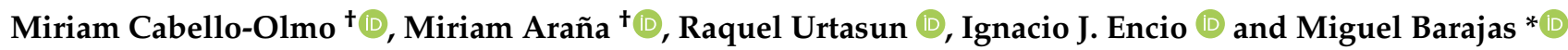 \\ Biochemistry Area, Department of Health Science, Public University of Navarre, 31008 Pamplona, Spain; \\ miriamcabelloolmo@gmail.com (M.C.-O.); miriam.arana@unavarra.es (M.A.); raquel.urtasun@unavarra.es (R.U.); \\ ignacio.encio@unavarra.es (I.J.E.) \\ * Correspondence: miguel.barajas@unavarra.es; Tel.: +349-4816-6143 \\ t These authors contributed equally to this work.
}

Citation: Cabello-Olmo, M.; Araña, M.; Urtasun, R.; Encio, I.J; Barajas, M. Role of Postbiotics in Diabetes Mellitus: Current Knowledge and Future Perspectives. Foods 2021, 10, 1590. https://doi.org/10.3390/ foods 10071590

Academic Editors: Paloma López and Maria Teresa Dueñas

Received: 4 June 2021

Accepted: 6 July 2021

Published: 8 July 2021

Publisher's Note: MDPI stays neutral with regard to jurisdictional claims in published maps and institutional affiliations.

Copyright: (c) 2021 by the authors. Licensee MDPI, Basel, Switzerland. This article is an open access article distributed under the terms and conditions of the Creative Commons Attribution (CC BY) license (https:// creativecommons.org/licenses/by/ $4.0 /)$.

\begin{abstract}
In the last decade, the gastrointestinal microbiota has been recognised as being essential for health. Indeed, several publications have documented the suitability of probiotics, prebiotics, and symbiotics in the management of different diseases such as diabetes mellitus (DM). Advances in laboratory techniques have allowed the identification and characterisation of new biologically active molecules, referred to as "postbiotics". Postbiotics are defined as functional bioactive compounds obtained from food-grade microorganisms that confer health benefits when administered in adequate amounts. They include cell structures, secreted molecules or metabolic by-products, and inanimate microorganisms. This heterogeneous group of molecules presents a broad range of mechanisms and may exhibit some advantages over traditional "biotics" such as probiotics and prebiotics. Owing to the growing incidence of DM worldwide and the implications of the microbiota in the disease progression, postbiotics appear to be good candidates as novel therapeutic targets. In the present review, we summarise the current knowledge about postbiotic compounds and their potential application in diabetes management. Additionally, we envision future perspectives on this topic. In summary, the results indicate that postbiotics hold promise as a potential novel therapeutic strategy for DM
\end{abstract}

Keywords: postbiotics; diabetes mellitus; bacteria-derived factors; bioactive compounds; functional foods; health benefits; lactic acid bacteria; gut microbiota; probiotics; paraprobiotics

\section{Introduction}

Since ancient times, our forefathers were aware of the importance of fermented foods and fermenting microorganisms for well-being, and in particular for intestinal health [1]. At present, the evidence for the role of the gastrointestinal microbiota (GM) in the host's health is robust, and this is because of the endocrine, digestive, and defensive functions achieved by our microbes [2-4]. Perturbations of the GM (dysbiosis) have been identified in several pathological states, including different forms of diabetes mellitus (DM), inflammatory bowel diseases, cancer, neurological diseases, psychiatric disorders, and even allergies, conditions in which the GM seemed to contribute, to some extent, to the disease onset and progression [5-8]. Moreover, a large number of investigations have demonstrated that strategies aimed at modulating the GM composition or activity, for instance, employing probiotics or prebiotics supplementations, are particularly useful for the restoration of the intestinal microbial environment and therefore for the host's health condition [9-11]. Probiotics and prebiotics are undoubtedly the most studied GM modulators. Probiotic refers to alive microorganisms that provide health benefits to the host through several mechanisms, including improvements of the intestinal barrier function, protection against pathogens, and the modulation of the immune response [12,13]. The most commonly used are species belonging to the genera Lactobacillus, Bifidobacterium, Streptococcus, and Lactococcus among 
bacteria and Saccharomyces among yeasts [14-16]. Prebiotics are non-living digestive microbial stimulants that are selectively fermented by our resident microbiota [17]. Hitherto, the term was used in essence for non-digestible fibres; however, the current definition also extends to bioactive compounds of different origin, such as polyunsaturated fatty acids and polyphenols [18].

In addition to the unquestionable beneficial effects of probiotics and prebiotics, emerging concepts are opening the door to new microbiome-based approaches. Figure 1 highlights the major historical milestones in microbiology, the biotics family, and health, along with other significant landmarks. Thanks to technological process in the last decades, tremendous advancements have taken place regarding the study, classification, and characterisation of the different probiotic-related concepts. Additionally, relevant is the foundation of The International Scientific Association for Probiotics and Prebiotics (ISAPP), which helps in the definition of the emerging concepts by providing expert consensus, among other activities. In addition to the new biotics terms, the notion of postbiotics has to be emphasised, which is a term first coined in 2012 by Tsilingiri and colleges [19] and recently updated in the ISAPP expert consensus document [20]. Experimental studies have indicated that microbial components can exhibit different bioactivities than their viable counterparts (probiotic) [21], which is why they present an attractive area for research. The category of postbiotics has gained significant interest; in fact, more than $87 \%$ of total scientific publications on this topic have been carried out in the past three years (according to Pubmed.gov, cosulted in June 2021).

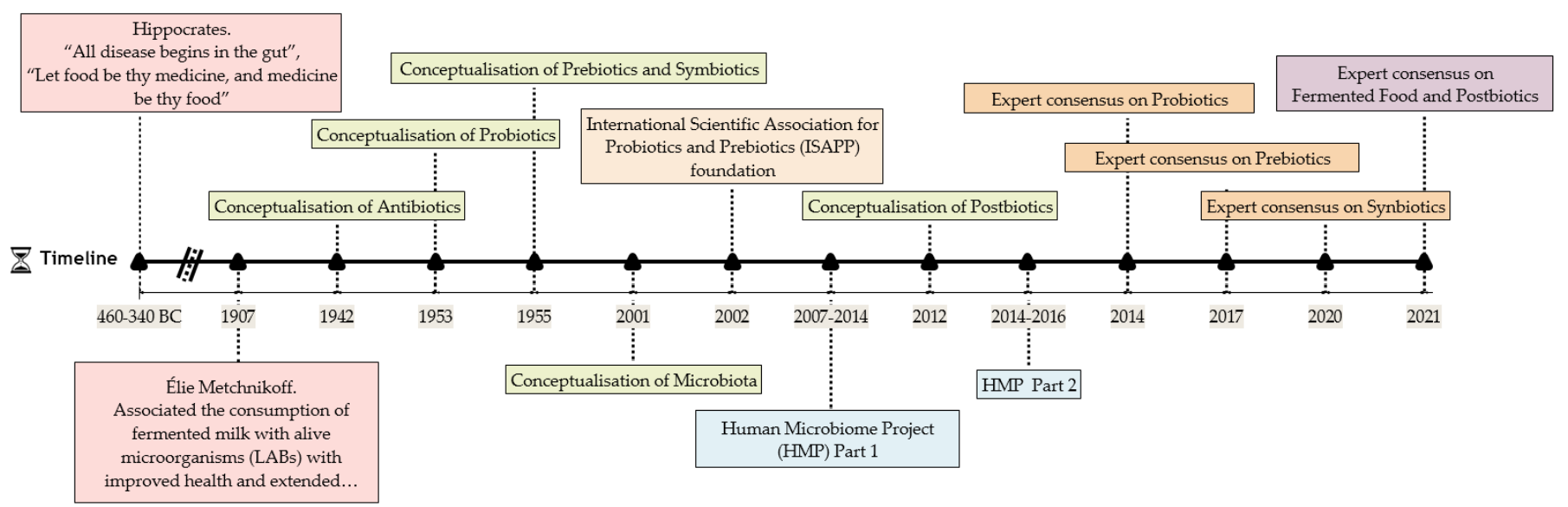

Figure 1. Timeline illustrating the main historical milestones in microbiology, the biotics family and health.

\subsection{Postbiotics}

Postbiotics refer to probiotic-derived products obtained from food-grade microorganisms that confer health benefits when administered in adequate amounts [22]. They include cell structures and secreted products or metabolic by-products that are discharged by viable microbial cells or that are collected and isolated after the cell lysis [23]. Most postbiotics are derived from bacteria, commonly Lactobacilli and Bifidobacterium members; however, fungal origin postbiotics are also investigated [24]. The newly published ISAPP postbiotic definition [20], "preparation of inanimate microorganisms and/or their components that confers a health benefit on the host", also includes inanimate microorganisms. At present, there are some commercial postbiotics, in the form of supplements or incorporated in food matrices, that are mostly intended for their use in gastrointestinal or immune-related pathologies [21]. Findings from previous studies are encouraging, and the future of postbiotics in other clinical applications, including different forms of DM $[25,26]$, seems promising and is the subject of this review. 


\subsubsection{Characteristics of Postbiotics}

The growing interest regarding postbiotics is partially explained by the advantages they provide, which are summarised in Figure 2. Briefly, (i) they are quite safe; (ii) they are well-tolerated and associated with reduced risk for adverse effects in vulnerable individuals (pregnant women, premature children, old adults, subjects immunocompromised or presenting an impaired immune function or intestinal barrier) [27-30]; (iii) they have no risk for transferring antibiotic-resistant genes to pathogenic or commensal bacteria [31]; (iv) their effectivity is independent of the cell viability, which ensures longer stability and improved shelf-life [20]; (v) they present an easy industrial (large-scale) production [32]; (vi) they show interesting technological properties (i.e., rheological properties of exopolysaccharides (EPS) in the food industry as a stabiliser $[32,33]$ or bio-preservative effects of LAB bacteriocins [34]). Other properties include (vii) the wide range of health-promoting effects they provide (See Figure 3), some of which can be reinforced in comparison with the effect of intact viable microbial cells [35]. Another very interesting feature of postbiotics is that, due to their nature, (viii) it appears feasible that they could be used with concurrent administration with antibiotic and antifungal agents.

\section{Postbiotics}

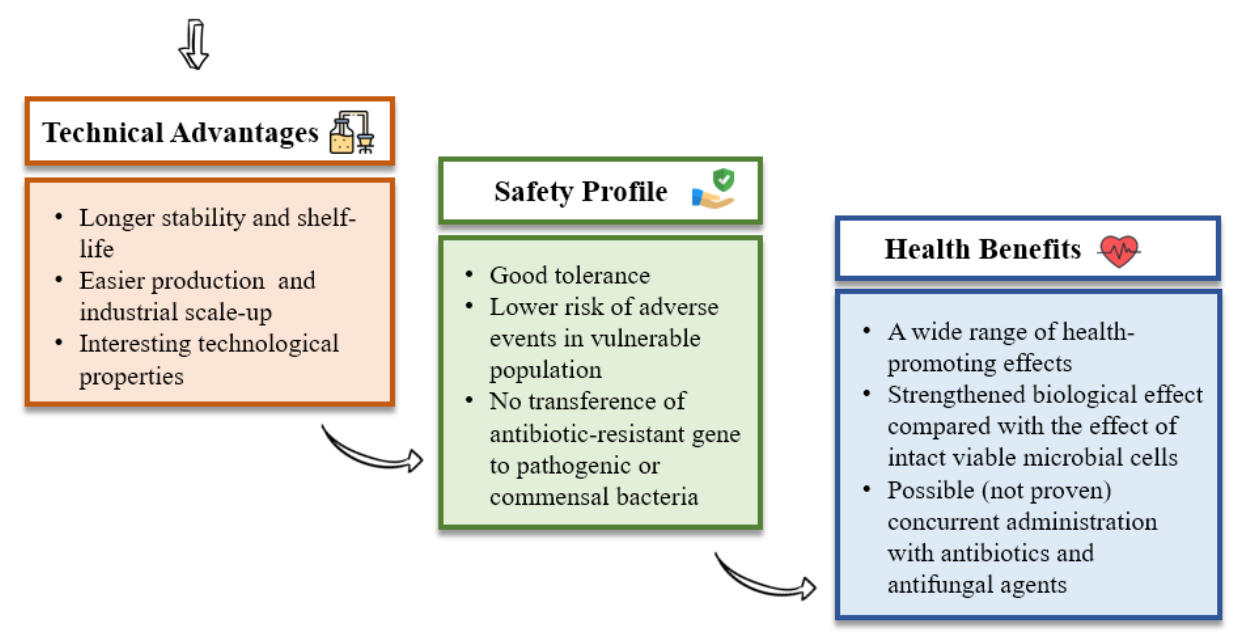

Figure 2. General characteristics of postbiotics.

\subsubsection{Classification}

The group of postbiotics covers a plethora of compounds. First, we find microbialderived metabolites, such as enzymes, proteins, peptides, organic acids, vitamins, minerals, bacteriocins, antimicrobial peptides, and extracellular vesicles (EVs) [31,34], along with other excreted molecules such as EPS [36]. Second, we find other molecules that shape the cell structure, including cell wall components, such as the polymers teichoic acids (lipoteichoic and wall teichoic acids), peptidoglycans, peptidoglycan-derived muropeptides, pili-type forms, and cell surface fractions (i.e., S-layer protein, mucus binding protein, fibronectin-binding protein) [23,32]. Third, other postbiotics are defined as cell-free extracts and lysates, culture supernatants, or biosurfactants (cell-wall-associated or intracellular) $[24,31]$. Last, as previously mentioned, inanimate microorganisms may also be considered in the postbiotic category [20,37].

The techniques utilised for the extraction and purification of postbiotics are many and varied. They must engage the microbial membrane and disturb the cell integrity to collect the intracellular content [21]. To mention some examples, solvent extraction, deproteinisation and precipitation, separation by electrophoresis and analysis with liquid chromatography or sonication, and hydrophobic gradient chromatography are among the applied techniques (reviewed in detail in [32]). Regarding microbial inactivation, different procedures or techniques can be used, including heat, high pressure, irradiation, or sonication $[37,38]$. 


\subsubsection{Health Benefits of Postbiotics}

Since the concept of postbiotic involves a broad range of compounds and substances diverse in nature and content (mentioned above), very different biological effects have been described (Figure 3). Some of these effects are restricted to the intestinal tract, for example, establishing a healthier GM [21,23], exerting prebiotics effect [36], or controlling the gut permeability $[39,40]$. Despite this, other effects not only affect the epithelial barrier but also cause systemic effects [24]. Collectively, the current evidence indicates that postbiotics can exert anti-inflammatory, antioxidant, immunomodulatory, pathogen inhibitory, anti-obesogenic, anticancer, antitumor, antiproliferative, antibiofilm, anti-adhesion, antihypertensive, hypocholesterolaemic, hepatoprotective, cardioprotective, anti-atherosclerotic, and anti-ulcerative effects (previously reviewed in $[23,24,31,32]$ ).

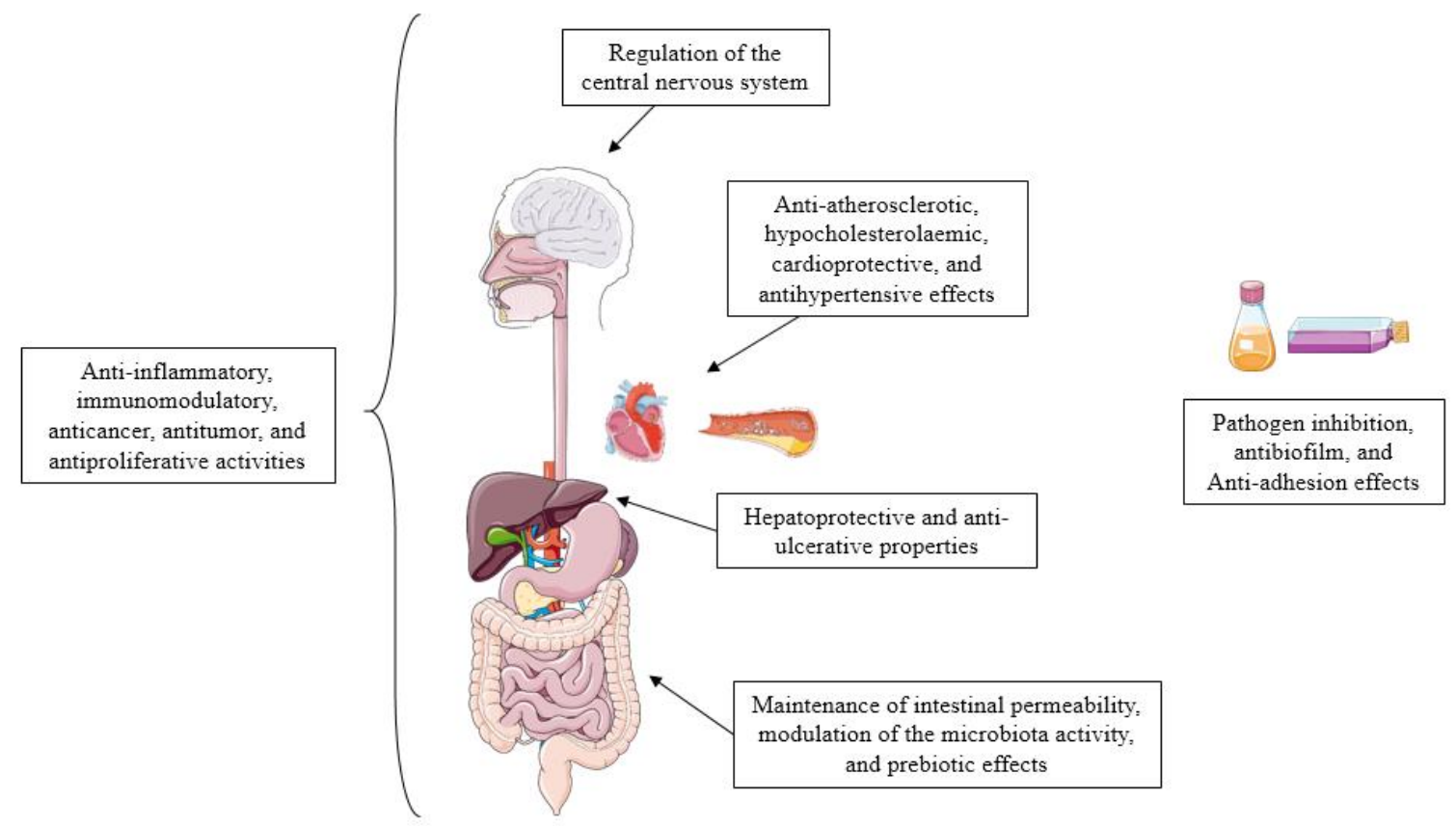

Figure 3. Potential mechanisms of action of postbiotics (illustrations from Smart ${ }^{\circledR}$ ).

It is important to emphasise that, similar to probiotics [18], it is likely that postbiotics properties are species- and strain-specific and depend on the microbial progenitor utilised for their formulation [21,41]. In addition to this, the type and activity of the resulting postbiotic will also depend on the substrate or matrix where the postbiotic compounds are produced [42].

The GM is probably the major source of postbiotic constituents. Our resident microbes release a myriad of products, including metabolites and also cell components (reviewed in detail in [43]), that behave as messengers in the microbiota-host interactions and are of major significance to the host $[44,45]$. In the present review, however, we focus on the potential of exogenous factors that are orally administered.

Finally, in addition to their use in the food industry and clinical applications, postbiotics have also been exploited in activities as varied as their use in animal health $[46,47]$ or sport performance [48].

\subsection{Lactic Acid Bacteria}

Lactic acid bacteria (LAB), such as Lactobacillus, Bifidobacterium, and Pediococcus spp., are without doubt the most important bacteria group in the food industry. They can be homofermentative or heterofermentative, depending upon their carbohydrate metabolism [36]. LABs have a long history of safe use [49] and are widely used in food processing, where they play important roles $[50,51]$. They act as cell factories and produce a plethora of poten- 
tially bioactive compounds including functional EPSs [33,52], enzymes [53], vitamins [54], anti-inflammatory substances [55], peptides [42], and antimicrobial products [34]. All of them show interesting technological attributes for food production and preservation, as well as exerting beneficial effects on human health, as described below.

\subsection{Microbiotherapy for Diabetes Mellitus Management}

Diabetes mellitus is a chronic disease characterised by elevated blood glucose levels (hyperglycaemia), originated by an autoimmune $\beta$-cell destruction (type 1 diabetes mellitus, T1DM) or a progressive loss of pancreatic function due to inadequate insulin secretion by the $\beta$ cells as a consequence of insulin resistance exerted by peripheral tissues such as liver, muscle, and adipose tissue (type 2 diabetes mellitus, T2DM) [56]. The epidemiological evidence indicates that $\mathrm{DM}^{\prime}$ s prevalence is reaching worrisome levels, and this scenario is exacerbated by poor diet quality, sedentarism, obesity pandemic, and the growing population aging, among other factors. The picture is alarming since DM is a major cause of death worldwide, and diabetes-specific complications are a leading cause of disability, particularly cardiovascular complications $[57,58]$.

During recent years, evidence has accumulated to support that the resident GM is among the set of environmental factors implicated in DM development and progression $[59,60]$. Possible explanations include the symbiotic relationship between the host and their intestinal microorganisms. The role of the resident microbes in the host's energy balance, metabolism, inflammation, and immunity is widely accepted [4,61-63]. The former are particularly interesting in the case of T2D, the latter is more involved in T1D development, and inflammation is a common factor between both forms of DM [64]. Additionally, the GM can also influence the host's homeostasis through other functions such as nutrient absorption, intestinal permeability, or controlling gene expression [65]. In connection with $\mathrm{DM}$, findings from experimental studies suggest that specific bacterial components could foster (LPS) [66] or protect (peptidoglycans) [67] from its onset or development. Furthermore, certain bacteria groups have been associated with improved glucose metabolism [66] or have been correlated with fasting blood glucose, $\mathrm{HbA1c}$, or even insulin levels [67]. Moreover, some GM derived-metabolites (i.e., bile acids, indole, short-chain fatty acids (SCFAs)) could either directly or indirectly modulate energy homeostasis and glucose metabolism [67].

Findings from cross-sectional and animal studies have shown that diabetic GM presents an unfriendly composition and activity, and some features are shared among T1D and T2D patients [68]. This "diabetic microbiota" includes a loss of butyrate-producing species, enrichment of opportunistic microorganisms, an overall lower gene count (abundance) associated with metabolic impairments, changes in nutrients' transport, enzymatic activity, and metabolism, all of this affecting SCFA concentrations and oxidative stress response, among others $[66,67,69]$. Moreover, diabetic patients commonly present gastrointestinal alternations (i.e., alteration of the bowel movement frequency) and have an increased risk for giving some gastrointestinal disorders [70]. DM has been linked to altered intestinal permeability, and a leaky gut has been reported in both T1D [71] and T2D [72]. This context favours the occurrence of metabolic endotoxemia [73] and bacteraemia [74], which, through an inflammatory response, influences insulin sensibility and, consequently, $\mathrm{DM}$ and metabolic complications.

Given the above, it is clear that a suitable GM and intestinal function is key for health maintenance and diabetes prevention, and it seems promising to tackle the diabetic disease through changes in GM composition and activity. In this light, a great number of studies have highlighted the therapeutic potential of microbiota-modulating dietary interventions in different forms of DM [75,76]. Although probiotics [77,78], prebiotics [79], and fermented foods [80-82] have served as a reference for microbiome-based interventions, postbiotics are emerging potential agents for DM prevention or management. Good evidence for this can be found in experimental studies in different models of diabetes mellitus $[83,84]$ and few human trials [85], as discussed below. 


\section{Objectives and Search Strategy}

The number of scientific articles examining postbiotic products for diabetes treatment or prevention is growing, which illustrates a considerable scientific interest in the topic. Nevertheless, to date, there is no review summarising the knowledge about this research topic. For this reason, the main objective of the present review was to provide insights into the currently available information on postbiotics in the context of DM, comprising microbial structures, metabolites, and inanimate microorganisms.

To perform a comprehensive review, we adopted the formalities of a systematic literature review. We conducted a search literature in MEDLINE (through PubMed) and Cochrane Library (CENTRAL) using key terms for postbiotic compounds ("bacteriocin", "biosurfactant", "cell-free extract", "conjugated fatty acid", "dead probiotic", "enzyme", "exopolysaccharides", "extract", "extracellular vesicles", "flavonoid", "GABA", "gamma-aminobutyric acid", "ghost probiotic", "inactivate probiotic", "lipoteichoic acid", "muropeptides", "neurotransmitter", "oligosaccharides", "paraprobiotic", "peptide", "peptidoglycan", "phenolic", "postbiotic", "protein", "SCFA", "short-chain fatty acid", "supernatant", "s-layer protein", "teichoic acid", "terpenoid", and "vitamin") combined with terms for diabetes mellitus ("diabetes mellitus", "type 1 diabetes", and "type 2 diabetes"). Reference lists of included articles were also hand searched. We excluded faecal material transplants and other compounds or strategies that do not fit exactly with the postbiotic definition.

\section{Results}

Since a specific molecule may exert different physiological effects, we considered it appropriate to present and discuss findings according to their organic structures. In the following sections, we provide information regarding cell components, secreted compounds, and inanimate probiotics. In accordance with the new postbiotic definition [20], neither purified substances nor filtrates where cell components were removed could be classified as postbiotics. Nevertheless, the current literature available lacks enough studies for postbiotics in diabetes prevention or management, and we decided to include a few studies revolving around GABA and EVs.

\subsection{Exopolysaccharides (EPSs)}

EPSs are usually divided into homopolysaccharides (dextran, levan) or heteropolysaccharides (kefiran) made up of one or more types of monosaccharides, respectively [86]. Despite their being originally membrane components and participating in cell adhesion and protection, they differ from other membrane structures since they can be released to the environment and exert different functions [36] (reviewed in [52]). Microbial EPS has been extensively studied, especially in the food industry, where they significantly impact food properties (texture or stability), provide new sensory attributes, and improve the nutritional value of food [36]. Outstanding among the many beneficial properties associated with EPS is their prebiotic effect [36,52].

Our search yielded a total of six preclinical cross-sectional studies involving microbial EPS and diabetes models, and no human trials were found (Table 1). All the animal studies were performed on T1D models (alloxan or streptozotocin induced rodents), and a further work used an insulin-resistant HepG2 cell model, which is a human hepatocellular carcinoma cell line often used in diabetes research [87]. With the exception of one study [88], a decreased glucose level in the blood (blood fasting glucose, FBG) or supernatant was reported, and two studies $[26,89]$ also observed an increase in insulin levels and an improved lipid profile. One study [83] reported that EPS from B. licheniformis was effective in counteracting oxidative stress and prevented diabetic complications by protecting key tissues and organs. One EPS from L. plantarum S1S2L2 resulted in the inhibition of pancreatic $\alpha$-amylase in vitro [90], which is a treatment option contemplated for DM management. Other observed findings in this study include the upregulation of genes involved in glucose metabolism, the reduction of some metabolic end-products, and the increase of hepatic glycogen reservoirs. 
Table 1. Experimental studies on microbial exopolysaccharides in diabetes mellitus.

\begin{tabular}{|c|c|c|c|c|c|}
\hline Type of Research & Bioactive Component & Source/Origin & Model System & Main Findings & Study \\
\hline \multirow{5}{*}{ Animal } & Levan & Bacillus licheniformis & $\begin{array}{l}\text { Wistar rats induced T1D with alloxan } \\
(150 \mathrm{mg} / \mathrm{kg} \mathrm{BW})\end{array}$ & $\begin{array}{l}\downarrow \text { Glycaemia, } \uparrow \text { glycogen level, } \downarrow \text { AST, ALT, } \\
\text { bilirubin, creatinine, and urea levels }\end{array}$ & Dahech et al., 2011 [83] \\
\hline & Levan & Bacillus subtilis (Natto) & $\begin{array}{l}\text { Wistar rats induced T1D with STZ } \\
\qquad(65 \mathrm{mg} / \mathrm{kg} \mathrm{BW})\end{array}$ & $\begin{array}{l}\text { No hypoglycaemic effect. No improvement of } \\
\text { diabetes symptoms }\end{array}$ & Bazani et al., 2012 [88] \\
\hline & Exopolysaccharide (unspecified) & Bacillus subtilis & $\begin{array}{l}\text { Sprague-Dawley rats induced T1D } \\
\text { with STZ }(65 \mathrm{mg} / \mathrm{kg} \mathrm{BW})\end{array}$ & $\begin{array}{l}\downarrow \mathrm{FBG}, \uparrow \text { serum insulin levels, } \downarrow \mathrm{TC}, \mathrm{LDL}, \mathrm{VLDL} \\
\text { and TG, } \uparrow \mathrm{HDL} \text { in treated vs. control rats }\end{array}$ & Ghoneim et al., 2016 [89] \\
\hline & $\begin{array}{l}\text { Selenium-enriched } \\
\text { exopolysaccharide }\end{array}$ & Enterobacter cloacaceae Z0206 & $\begin{array}{l}\text { Female ICR mice induced T1D with } \\
\text { alloxan }(190 \mathrm{mg} / \mathrm{kg})\end{array}$ & $\begin{array}{c}\downarrow \mathrm{FBG}, \uparrow \text { serum insulin level, } \downarrow \text { glycosylated } \\
\text { serum protein, } \uparrow \mathrm{BW}, \downarrow \mathrm{TC} \text { and TG in treated } \\
\text { vs. control mice }\end{array}$ & Jin et al., 2012 [26] \\
\hline & Exopolysaccharide (unspecified) & Sorangium cellulosum NUST06 & $\begin{array}{l}\text { Mice (Kunming strain) induced T1D } \\
\text { with alloxan }(250 \mathrm{~mL} / \mathrm{kg} \mathrm{BW})\end{array}$ & $\begin{array}{l}\downarrow \mathrm{FBG} \text { in both healthy and alloxan-induced } \\
\text { diabetic mice }\end{array}$ & Ding et al., 2004 [91] \\
\hline Cell line & Exopolysaccharide (unspecified) & Lactobacillus plantarum H31-2 & In vitro, insulin-resistant HepG2 cells & $\begin{array}{l}\downarrow \text { Supernatant glucose concentration of } \\
\text { insulin-resistant HepG2 cells, inhibition of } \\
\text { pancreas } \alpha \text {-amylase, upregulation of the } \\
\text { expression of GLUT-4, Akt-2, and AMPK }\end{array}$ & Huang et al., 2020 [90] \\
\hline
\end{tabular}

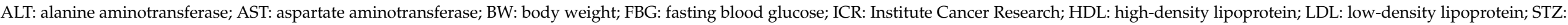
streptozotocin; TC: total cholesterol; TG: triglyceride; T1D: type 1 diabetes; VLDL: very-low-density lipoprotein. $\uparrow$ means increase, $\downarrow$ means decrease. 
While some EPSs caused a hypoglycaemic effect, another study failed to demonstrate any hypoglycaemic effect [88]. This illustrates the specific effect of postbiotics and evidences the need to indicate the characteristics of the studied molecule and the identity of the progenitor microorganism. Still, some studies did not specify the probiotic strain used $[83,88,89]$, and this slows the progress of science. In addition, none of the studies mentioned above analysed the possible changes of the microbiota.

Although we searched for other cell membrane elements, we did not identify any study involving oligosaccharides, s-layer proteins, teichoic acids, peptidoglycan, or muropeptides on DM.

\section{2. $G A B A$}

GABA is a neurotransmitter and neuromodulator produced by $\beta$ cells [92] that can also be produced by certain bacteria $[93,94]$. In addition to its important inhibitory effect in the central nervous system, increasing evidence has indicated that GABA can induce insulin production (insulinotropic effect), enhance glucose tolerance and insulin sensitivity, control the $\beta$ cells mass, and exert anti-inflammatory and immunomodulatory effects, all of which are interesting in DM [92,95-97]. Indeed, an elegant study demonstrated that GABA signalling is compromised in T2D [98]. All this explains the growing interest in GABA in DM.

We identified two experimental studies examining the ability of GABA synthesised by probiotics to improve glucose metabolism and control glycaemia in rodent models of T1D and T2D (Table 2). The supplementation with yogurt fermented with a GABA-producing probiotic (S. thermophiles fmb5) in high-fat diet (HFD) and STZ-induced T2DM mice led to improved glucose tolerance and insulin sensitivity, probably due to a preserved pancreatic function and normalised organ function [95]. Besides the experimental product included remnants of probiotic cells, the beneficial properties were attributed to the GABA content.This intervention was ineffective in reducing FBG that, by contrast, was observed with a mung bean extract fermented with Mardi rhizopus 5351 [84]. This mould displayed important antihyperglycaemic and antioxidant properties and also improved some components of the lipid profile in glucose- and alloxan-induced hyperglycaemic mice. Although GABA represents a promising approach, the existing literature does not indicate a strong antidiabetic or hypoglycaemic effect for this neuromodulator. We observed an important dose-response effect, and a greater effect was found with the highest GABA doses [84,94]. This feature must be considered in future studies.

\subsection{Extracellular Vesicles (EVS)}

EVs are spherical particles secreted by bacteria and other microorganisms, which discharge their cellular content, including proteins, polysaccharides, enzymes, and toxins among others. They enable the dialogue between microbial cells. Additionally, they can communicate with the host through microbe- and pathogen-associated molecular patterns (MAMP and PAMP, respectively), leading to an immunomodulatory action. The GM is a good source of EVs that move beyond the intestine and disseminate to other organs and tissues [44,99]. Furthermore, host cells also secrete EVs and recent evidence suggests that they could also play a role in the development and progression of T1D and T2D [100,101]. We identified a single study on EVs in which EVs from A. municiphila showed to improve the intestinal barrier function and glucose tolerance in HFD-induced T2D mice [40] (Table 2), and such effect was probably because of the observed changes in tight junction proteins, which prevented or reduced the risk of metabolic endotoxaemia. This study also demonstrated that EVs enhanced the barrier function in vitro experiments with Caco2 cells. 
Table 2. Experimental studies on the effects of GABA and EVs in diabetes mellitus.

\begin{tabular}{|c|c|c|c|c|}
\hline Compound & Source/Origin & Model System & Main Findings & Study \\
\hline \multirow[b]{2}{*}{ GABA } & $\begin{array}{c}\text { GABA-containing } \\
\text { fermented mung bean } \\
\text { extract with Mardi rhizopus } \\
5351 \text { inoculums, low and } \\
\text { high doses }\end{array}$ & $\begin{array}{l}\text { T1D Balb/c induced T1D } \\
\text { with high doses of alloxan } \\
(100 \mathrm{mg} / \mathrm{kg} \mathrm{BW}) \text { and } \\
\text { glucose-induced } \\
\text { hyperglycaemic } \\
\text { Balb/c mice }\end{array}$ & $\begin{array}{c}\text { Glucose-induced mice: } \downarrow \text { FBG } \\
\text { Alloxan-induced mice: } \downarrow \text { Reduced } \\
\text { FBG, } \uparrow \text { insulin serum levels, } \downarrow \text { TC and } \\
\text { TG serum levels (vs. nonfermented), } \\
\text { restored antioxidant status } \\
(\downarrow \text { MDA and NO) }\end{array}$ & Yeap et al., 2012 [84] \\
\hline & $\begin{array}{l}\text { Yogurt fermented with } \\
\text { Streptococcus thermophiles } \\
\text { fmb5, low and high doses }\end{array}$ & $\begin{array}{l}\text { C57BL / } 6 \text { mice induced } \\
\text { T2D with low doses of } \\
\text { STZ (100 mg/kg BW) }\end{array}$ & $\begin{array}{c}\text { Low and high doses: No } \\
\text { hypoglycaemic effect, } \uparrow \text { HOMA- } \beta \text {, } \\
\text { improved glucose tolerance and } \\
\text { insulin resistance, normalised fat, } \\
\text { kidney and liver coefficients, } \downarrow \text { serum } \\
\text { urea nitrogen, no effect on HbA1c } \\
\text { nor BW. } \\
\text { High doses: Normalised pancreatic } \\
\text { histology, preserved islet cells } \\
\text { function, } \downarrow \text { TC and LDL, HDL }\end{array}$ & Li et al., 2020 [95] \\
\hline EVs & $\begin{array}{c}\text { Akkermansia muciniphila } \\
\text { ATCC BAA-835 }\end{array}$ & $\begin{array}{l}\text { C57BL / } 6 \text { mice induced } \\
\text { T2D with HFD }\end{array}$ & $\begin{array}{l}\text { In vivo: Reduced BW, attenuated } \\
\text { intestinal damage following HFD, } \\
\text { increase expression of tight junction } \\
\text { proteins, improved glucose } \\
\text { tolerance (OGTT) } \\
\text { In vitro: Enhanced barrier function } \\
\text { in Caco-2 cells }\end{array}$ & Chelakkot et al., 2018 [40] \\
\hline
\end{tabular}

AUC: area under the curve; BW: body weight; EVs: extracellular vesicles; FBG: fasting blood glucose; GABA: $\gamma$-aminobutyric acid; GIP: gastric inhibitory polypeptide; GLP-1: glucagon-like peptide-1; GM: gut microbiota; HFD: high fat diet; HOMA: homeostasis model assessment- $\beta$; LDL: low-density lipoprotein; MDA: malondiadehyde; NO: nitric oxide; OGTT: oral glucose tolerance test; PYY: peptide YY; STZ: streptozotocin; TC: total cholesterol; TG: triglyceride; T1D: type 1 diabetes; T2D: type 2 diabetes. $\uparrow$ means increase, $\downarrow$ means decrease.

\subsection{Supernatants, Extracts, and Surfactants}

Our search yielded several studies on microbial supernatants, extracts, and surfactants, mainly on Lactobacillus and Bacillus probiotic species (See Table 3). Half of them were in vitro experiments and the other half animal studies in T1D- and T2D-induced mice. Controls varied from tap water [102] to phosphate-buffered saline [103] or commercial antidiabetic drugs [104,105].

Alpha-glucosidase inhibitors (AGI) are a group of antidiabetic drugs whose main function is reducing carbohydrate catabolism and thus minimising glucose availability and controlling glycaemic levels [106]. One study analysed the $\alpha$-glucosidase inhibitory activity of five different $L$. plantarum strains' cell-free supernatants, all of which demonstrated the ability to reduce glucose degradation, especially L. plantarum CCFM0236. The authors could confirm the beneficial effects of live L. plantarum CCFM0236 in a T2D murine model, resulting in a hypoglycaemic effect, improved insulin resistance and antioxidant capacity, preserved pancreatic function, and reduced inflammation [107]. Another study included eight LABs isolated from commercial water kefir grains, and the authors also evaluated cell-free extracts [108]. A similar study focused on the dipeptidyl peptidase IV (DPP-IV) inhibitory activity and the antioxidant activity of fourteen Lactobacillus strains isolated from traditional fermented foods [109]. DPP-IV is another pharmacological target for diabetes treatment [110]. The in vivo beneficial properties widely varied among the Lactobacillus strains, reinforcing the need to independently analyse each of the strains. The last work was conducted to investigate the antidiabetic effects of a soybean extract previously fermented with B. subtilis MORI [102]. The supplementation with a postbiotic derived from this microorganism prevented hyperglycaemia and oxidative stress in T1D animals but had no significant effects in healthy non-diabetic animals. 
Table 3. Experimental evidence on the effects of microbial supernatants, extracts, and biosurfactants in diabetes mellitus.

\begin{tabular}{|c|c|c|c|c|c|c|}
\hline $\begin{array}{l}\text { Type of } \\
\text { Research }\end{array}$ & Component & Bioactive Molecule(s) & Source/Origin & Model System (If Apply) & Findings & Study \\
\hline \multirow{4}{*}{ Animal } & Supernatant & Supernatant & Lactobacillus rhamnosus GG & $\begin{array}{l}\text { C57BL/6J induced metabolic } \\
\text { dysfunction with HFFD and } \\
\text { intermittent hypoxia }\end{array}$ & $\begin{array}{l}\downarrow \text { FBG (vs. baseline values), } \uparrow \text { insulin sensitivity, } \uparrow \text { energy } \\
\text { expenditure, improved body composition (fat and } \\
\text { muscle mass), } \downarrow \text { TC and TG, } \uparrow \text { NEFAs, } \uparrow \text { total faecal } \\
\text { SFCAs, } \downarrow \text { proinflammatory cytokines expression, } \\
\text { downregulated lipogenesis, upregulated lipid oxidation }\end{array}$ & Liu et al., 2020 [103] \\
\hline & Extract & $\begin{array}{l}\text { Fermented soybean extracts } \\
\text { (served dried with corn starch), } \\
\text { low and high doses }\end{array}$ & $\begin{array}{l}\text { Bacillus subtilis MORI/Isolated from } \\
\text { Chungkookjang }\end{array}$ & $\begin{array}{l}\text { Wistar rats induced T1D with } \\
\text { STZ }(55 \mathrm{mg} / \mathrm{kg})\end{array}$ & $\begin{array}{c}\text { Low and high doses (vs. diabetic controls): } \uparrow \text { BW, } \\
\text { attenuated rise in FBG, } \downarrow \text { food and water intake, } \downarrow \text { MDA } \\
\text { serum levels, } \uparrow \text { CAT and GSH-Px activity, improved } \\
\text { vascular function } \\
\text { High doses (vs. diabetic control): } \uparrow \text { serum insulin levels } \\
\text { and SOD levels }\end{array}$ & Lim et al., 2012 [102] \\
\hline & \multirow[t]{2}{*}{ Biosurfactant } & \multirow[t]{2}{*}{$\begin{array}{l}\text { Biosurfactant (served as crude } \\
\text { lipopeptide preparation) }\end{array}$} & \multirow[t]{2}{*}{$\begin{array}{l}\text { Bacillus subtilis SPB1/Isolated from } \\
\text { Tunisian soil }\end{array}$} & $\begin{array}{l}\text { Wistar rats induced T1D with } \\
\quad \text { alloxan }(150 \mathrm{mg} / \mathrm{kg})\end{array}$ & $\begin{array}{l}\downarrow \text { FBG and } \alpha \text {-amylase activity in the plasma, } \downarrow \text { TC, TG, } \\
\text { and LDL levels, } \uparrow \text { HDL levels, protected tissues } \\
\text { (pancreatic } b \text { cells, liver, intestine, and kidney) }\end{array}$ & Zouari et al., 2015 [104] \\
\hline & & & & $\begin{array}{l}\text { Wistar rats induced T2D with } \\
\text { HFFD }\end{array}$ & $\begin{array}{l}\downarrow F B G \text {, improved glucose tolerance (OGTT), normalised } \\
\text { serum } \alpha \text {-amylase activity }\end{array}$ & Zouari et al., 2017 [105] \\
\hline \multirow[b]{3}{*}{ In vitro } & \multirow[b]{3}{*}{ Supernatant } & CFS & $\begin{array}{l}\text { Five Lactobacillus plantarum strains: } \\
\text { CCFM0236, CCFM 12, CCFM 10, } \\
\text { CCFM0311, and CCFM } 23\end{array}$ & - & $\alpha$-glucosidase inhibitory activity (\%): from 14.5 to 32.2 & Li et al., 2016 [107] \\
\hline & & CFE and CFS & $\begin{array}{l}8 \mathrm{LAB} \text { isolates (K1, K8, K16, K19, } \\
\text { K29, K35, K45, K96, and } \\
\text { LGG)/Isolated from commercial } \\
\text { water kefir grains }\end{array}$ & - & $\begin{array}{l}\alpha \text {-glucosidase inhibitory activity (\%): from } 5.2 \text { to } 39.4 \text { in } \\
\text { CFS, from } 2.3 \text { to } 15.5 \text { in CFE }\end{array}$ & Koh et al., 2018 [108] \\
\hline & & CFE, CFS and CFES & $\begin{array}{l}14 \text { Lactobacillus spp. strains/Isolated } \\
\text { from traditional fermented products }\end{array}$ & - & $\begin{array}{l}\text { DPP-IV inhibitory activity (\%): from } 0 \text { to } 55.4 \text { in CFE, } \\
\text { from } 0 \text { to } 7.13 \text { in CFES/reducing activity (mmol of } \\
\text { cysteine): from } 73.3 \text { to } 189.7 \text { in CFS, from } 53.0 \text { to } 159.7 \text { in } \\
\text { CFE/DPPH free radical-scavenging activity (\%): from } \\
36.8 \text { to } 62.1 \text { in CFS, from } 12.9 \text { to } 34.5 \text { in CFE/hydroxyl } \\
\text { radical scavenging activity: from } 13.7 \text { to } 68.6 \text { in CFS; from } \\
15.9 \text { to } 38.8 \text { in CFE/superoxide anion radical scavenging } \\
\text { activity (\%): from } 2.6 \text { to } 16.2 \text { in CFS; from } 12.2 \text { to } 43.3 \text { in } \\
\text { CFE/lipid peroxidation inhibiting capacity (\%): from } 1.5 \\
\text { to } 18.5 \text { in CFS; from } 5.9 \text { to } 31.4 \text { in CFE. }\end{array}$ & Yan et al., 2020 [109] \\
\hline
\end{tabular}

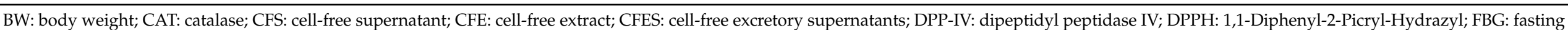

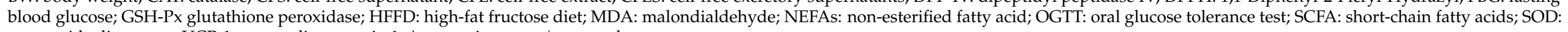
superoxide dismutase; UCP-1: uncoupling protein 1 . $\uparrow$ means increase, $\downarrow$ means decrease 
Biosurfactants are surface-active compounds with low or high molecular weight that help in a number of vital functions for cell homeostasis. Examples include lipoproteins and lipopeptides, glycolipids, fatty acids, lipopolysaccharides and heteropolysaccharides, and polymeric biosurfactants. Due to their properties, they present many technological applications (food industry, cosmetics, home care products, etc.) and could offer health benefits [111,112]. We found two studies evaluating the antidiabetic effect of $B$. subtilis SPB1 biosurfactant in T1D [104] and T2D [105]. The biosurfactant displayed hypoglycaemic effect and normalised serum $\alpha$-amylase activity in both models, improved glucose tolerance in T2D animals, and improved the lipid profile and organ functions in T1D animals. These findings suggest that $B$. subtilis SPB1 biosurfactant may be a promising therapeutic agent for ameliorating different forms of DM. Finally, we identified one study that evaluated the in vivo effect of L. rhamnosus GG surfactant in a model of metabolic disorders [103]. The findings revealed that the treatment improved insulin sensitivity, protected from hyperlipidaemia, and also prevented hepatic steatosis in the animals.

In the above-mentioned studies, the in vitro assays were performed with the purpose of identifying the strains that would, theoretically, exert the greatest hypoglycaemic effect in vivo and thus be regarded as antidiabetic probiotic candidates. Despite most of these supernatants and preparations not being intended for use as postbiotics, they exerted interesting antidiabetic effects, and more studies are needed to validate these findings.

With our search, we were able to identify a large number of research works performed on microbial-derived compounds, such as cell-wall muramyl-peptide [113], conjugated linoleic acids [114,115], or SCFAs [116-118], that were not obtained from a specific bacteria culture but were purchased commercially as a laboratory reagent. Although many of these products probably have a microbial origin, we decided not to include these scientific works since they do not contemplate the source and, as previously suggested, the identity of the producer microorganism has a significant influence on postbiotic functional properties.

\subsection{Inanimate Microorganisms}

Inanimate microorganisms, formerly referred to as paraprobiotics or ghost probiotics, have been extensively studied. They can be achieved by very different methods that will strongly determine their functional properties [119]. Although they are known to exert important immunomodulatory activities, they demonstrated benefits in very different conditions [37]. Our search yielded four experimental cross-sectional studies in murine models and two human trials (Table 4). The inactivation methods included heat, pressure, irradiation, and ohmic treatments. Only two studies [25,85] confirmed the absence of viable microbial cells in the preparations with inanimate preparations by culture-based analysis (plate count), and only two studies described changes in the GM [25,120]. A first study evaluated a live and inanimate multi-species probiotic and observed that both formulas were effective in reducing FBG, improving glucose tolerance, protecting pancreatic cells, and altering the intestinal tract modifying enteroendocrine cells, intestinal microbiota, and SCFA levels [25]. The authors brought together all the findings and concluded that the live probiotic was certainly more competent than the inanimate version, and it was hypothesised to be due to important changes in the intestinal environment, involving the inflammatory tone and the microbiota composition. In a second study, non-viable B. longum BR-108 presented a hypoglycaemic effect, reduced body weight gain and adiposity, and improved lipid profile in genetically obese mice [121]. The authors suggested that the inanimate probiotic could have provoked a hepatoprotective activity that explains such findings. Another study was performed in healthy rats fed with pasta enriched with either live or inanimated B. animalis subsp. lactis Bb-12 [120]. Both versions showed hypoglycaemic and hypocholesterolaemic effects as compared with the control group. The inanimation method (irradiation) barely changed the probiotic activity, and the only differences between the active and inanimate probiotic were related to the intestinal microbiota composition. The authors emphasised that the food matrix influences the action of the inanimate microorganism in a very significant manner, and therefore this aspect must be considered when 
discussing and extrapolating findings. The last study used the pasteurisation method to inactivate A. muciniphila and demonstrated that the postbiotic retained the beneficial effects described for the probiotic. Moreover, the pasteurised A. muciniphila improved certain parameters such as IR index, goblet cell density, normalisation of adipocyte diameter, and leptin levels in C57BL/6J mice fed with HFD diet [122].

Table 4. Experimental and clinical studies on the effects of inanimate probiotics in diabetes mellitus and health.

\begin{tabular}{|c|c|c|c|c|c|}
\hline $\begin{array}{l}\text { Type of } \\
\text { Research }\end{array}$ & Microorganism & Inactivation Method & Model System & Main Findings & Study \\
\hline \multirow{4}{*}{ Animal } & $\begin{array}{c}\text { Lactobacillus casei } \\
\text { CCFM419, } \\
\text { L. plantarum } \mathrm{X} 1, \\
\text { L. rhamnosus } \mathrm{Y} 37, \\
\text { L. brevis CCFM648, and } \\
\text { L. plantarum CCFM36 }\end{array}$ & $\begin{array}{l}\text { Heat treatment }\left(80^{\circ} \mathrm{C}\right. \\
\text { for } 30 \mathrm{~min})\end{array}$ & $\begin{array}{l}\text { C57BL/6J mice induced } \\
\text { T2D with STZ } \\
(100 \mathrm{mg} / \mathrm{kg} \mathrm{BW})\end{array}$ & $\begin{array}{l}\text { Inanimate probiotic: } \uparrow \text { Serum IL-6 } \\
\text { levels and faecal acetic levels } \\
\text { Live probiotic: Improved insulin } \\
\text { tolerance, normalised serum IL-10, } \\
\text { TNF- } \alpha \text { and IL- } 6 \text { levels, } \uparrow \text { faecal } \\
\text { acetic and butyrate levels, } \uparrow \text { faecal } \\
\text { Lactobacillus, Akkermansia, and } \\
\text { Bifidobacterium genera, } \\
\uparrow \text { faecal actinobacteria (\%) } \\
\text { Both: } \downarrow \text { FBG, normalisation of } \\
\text { HbA1c and leptin levels, } \uparrow \text { ileum L } \\
\text { cell levels, } \uparrow \text { faecal } \\
\text { Firmicutes/Bacteroidetes ratio } \\
\text { Both with stronger effect with live } \\
\text { probiotics: Improved glucose } \\
\text { tolerance, protection of pancreatic } \\
\text { histological characteristics }\end{array}$ & Li et al., 2016 [25] \\
\hline & $\begin{array}{l}\text { Bifidobacterium longum } \\
\text { BR-108; low, medium, } \\
\text { and high doses }\end{array}$ & $\begin{array}{l}\text { Heat and pressure } \\
\text { treatment } \\
\text { (autoclaved at } 105^{\circ} \mathrm{C} \\
\text { for } 20 \mathrm{~min} \text { ) }\end{array}$ & $\begin{array}{l}\text { Tsumura Suzuki obese } \\
\text { diabetes (TSOD) mice } \\
\text { (genetically obese mice) }\end{array}$ & $\begin{array}{c}\text { All the doses: } \downarrow \text { BG gain (vs. control } \\
\text { mice), } \downarrow \text { adipose tissue } \\
\text { accumulation, no differences in } \\
\text { food consumption, } \downarrow \text { serum } \\
\text { creatinine levels } \\
\text { Medium and high doses: } \downarrow \text { FBG, } \\
\downarrow \text { NEFAs, } \downarrow \text { creatinine urine levels } \\
\text { Medium dose: } \downarrow \text { TC } \\
\text { High doses: Improved glucose } \\
\text { tolerance (OGTT), } \downarrow \text { TG }\end{array}$ & $\begin{array}{l}\text { Ben Othman et al., } \\
2019[121]\end{array}$ \\
\hline & $\begin{array}{l}\text { Bifidobacterium animalis } \\
\text { subsp. lactis } \mathrm{Bb}-12, \\
\text { incorporated in } \\
\text { wheat pasta }\end{array}$ & $\begin{array}{l}\text { Irradiation } \\
\text { (gamma-irradiation on } \\
\text { ice, at } 2.5 \text { Kilogray) }\end{array}$ & Healthy Wistar rats & $\begin{array}{l}\text { Control and paraprobiotic pasta: } \\
\downarrow \text { FBG and TC (vs. control diet), no } \\
\text { differences in food consumption } \\
\text { and BW, TG, HDL, AST, ALT, and } \\
\text { microbiota alpha-diversity indexes } \\
\text { Paraprobiotic pasta: Differential } \\
\text { microbiota composition (vs. control } \\
\text { diet and control pasta) }\end{array}$ & Almada et al., 2021 [120] \\
\hline & Akkermansia muciniphila & $\begin{array}{l}\text { Pasteurised }\left(70{ }^{\circ} \mathrm{C} \text { for }\right. \\
30 \mathrm{~min})\end{array}$ & $\begin{array}{l}\text { C57BL / 6J mice (normal } \\
\text { chow or high-fat diet) }\end{array}$ & $\begin{array}{c}\downarrow \text { IR index, } \uparrow \text { faecal caloric content, } \\
\uparrow \text { goblet cell density, normalisation } \\
\text { of adipocyte diameter and } \downarrow \text { leptin } \\
\text { levels (vs. live microorganism) }\end{array}$ & Plovier et al., 2017 [122] \\
\hline \multirow[t]{2}{*}{ Human } & $\begin{array}{l}\text { Lacticaseibacillus casei } 01 ; \\
\text { in whey-grape } \\
\text { juice drink }\end{array}$ & $\begin{array}{l}\text { Ohmic heating }(8 \mathrm{~V} / \mathrm{cm} \text {, } \\
\left.95^{\circ} \mathrm{C} / 7 \mathrm{~min}, 60 \mathrm{~Hz}\right)\end{array}$ & $\begin{array}{l}\text { In vitro experiments; } \\
\text { healthy volunteers } \\
\qquad(\mathrm{n}=15)\end{array}$ & $\begin{array}{c}\text { Preliminary in vitro experiments: } \\
\text { Live and inanimate probiotic had } \\
\alpha \text {-glucosidase and } \alpha \text {-amylase } \\
\text { inhibitory activities } \\
\text { Postprandial glucose levels in } \\
\text { healthy volunteers: Accelerated } \\
\text { increase in PBG with the probiotic } \\
\text { and inanimate probiotic drinks (vs. } \\
\text { control) due to differences in sugar } \\
\text { content with the control (water), no } \\
\text { differences in AUC values, } \\
\text { inanimate probiotic had a similar } \\
\text { effect to control. }\end{array}$ & Barros et al., 2021 [85] \\
\hline & Akkermansia muciniphila & Pasteurised & $\begin{array}{l}\text { Volunteers with excess } \\
\text { body weight } \\
\text { (overweight or obese), } \\
\text { insulin resistance and a } \\
\text { metabolic syndrome }\end{array}$ & $\begin{array}{c}\downarrow \text { insulin levels, improved insulin } \\
\text { sensitivity index, fasting glycaemia } \\
\text { and } \mathrm{HbA} 1 \mathrm{c} \text { were not modified (vs. } \\
\text { placebo group) }\end{array}$ & $\begin{array}{l}\text { Depommier et al., } \\
2019 \text { [123] }\end{array}$ \\
\hline
\end{tabular}

ALT: alanine aminotransferase; AST: aspartate aminotransferase; AUC: area under the curve; BW: body weight; FBG: fasting blood glucose; HbA1c: glycated haemoglobin; HDL: high-density lipoprotein; IR: insulin resistance index; NEFAs: non-esterified fatty acid; OGTT: oral glucose tolerance test; PBG: postprandial blood glucose; STZ: streptozotocin; TC: total cholesterol; TG: triglyceride; T1D: type 1 diabetes; T2D: type 2 diabetes.

We identified two human trials. The first study was a randomised and controlled crossover study, and it was performed in a reduced sample of healthy individuals; the findings indicate that the intake of live or inanimate Lacticaseibacillus casei 01 in a whey- 
grape juice with white bread can attenuate the glucose response expected [85]. Both formulas had an impact similar to the control drink (water), especially the inanimate probiotic preparation. These findings sustain the hypoglycaemic effect that was previously confirmed in a preliminary in vitro experiment. The second trial was a randomised doubleblind placebo-controlled proof-of-concept and feasibility study using alive or pasteurised $A$. municiphila. Individuals with excess body weight (overweight or obese), insulin resistance, and a metabolic syndrome were enrolled and received placebo, live, or pasteurised $A$. municiphila ( $10^{10}$ bacteria per day) for 3 months. No adverse effects were observed, and the main results obtained were reduced plasma insulin levels, no differences in fasting blood glucose, and improvement of the insulin sensitivity index compared with the placebo group [123].

\section{Discussion}

The scientific literature examining the effects of postbiotics in DM is scarce compared with the number of publications focusing on probiotics, prebiotics, or fermented foods. Additionally, the majority of the included studies were published in the last ten years, and this may indicate that this research field is still in its infancy and that much knowledge remains to be discovered. Most eligible studies investigated compounds from probiotic bacteria, including Gram-positive (Lactobacillus, Bacillus, Bifidobacterium, and Streptococcus) and Gram-negative species (Enterobacter, Sorangium, and Akkermansia), and only one study evaluated a mould (Rhizopus) [84]. None of the studies considered postbiotics obtained from probiotic yeasts, even though they elicit many biological effects as well [24]. Although there were studies in different models of DM, studies on T1D outnumber studies on T2D.

The type of outcome measured widely differed among the different types of postbiotics. This is an expected result since several effects can be observed depending on the kind of molecule analysed. For example, according to previous study, it is likely that extracellular components exert metabolic activities, while cell components perform protective and antimicrobial functions [53]. Many studies have focused on key enzymes implicated in carbohydrate breakdown and metabolism. Previous studies on probiotics have demonstrated that some strains present an inhibitory effect on $\alpha$-glucosidase activity [77,124], and the same was confirmed in EPS and cell-free supernatant. In the same line, supernatants from LABs also exhibited DPP-IV inhibitory activity, which was also described in fermented products [125]. At this point, scientists must consider postbiotics as a potential line of research for the development of natural AGI and DPP-IV inhibitors. In this sense, in a previous study one probiotic strain was genetically manipulated to produce $\beta$-lactoglobulin that included peptides with DPP-IV-inhibiting activity [126]. In the same line, another study modified one E. coli strain to synthesise $\mathrm{N}$-acylphosphatidylethanolamines that showed protection against obesity-associated complications such as insulin resistance, adiposity or hepatosteatosis in animals [127]. This opens new opportunities for genetically modified organisms able to produce large amounts of compounds with biological effects that may be beneficial for DM management.

As introduced above, DM is frequently associated with leaky gut and gastrointestinal complications. Thus, other potential areas for future research may focus on intestinal permeability and integrity, as previously described in EVs from A. municiphila [40], intestinal peptides produced by modified probiotic bacteria [128], or soluble proteins such as p40 or p75 [20]. For example, one study identified a functional peptide from S. epidermidis JA1 supernatant that enhanced glucagon-like peptide-1 in NGN3-Human intestinal enteroid cells [129]. When the active bacteria was tested in vivo in HFD mice, it showed protection against metabolic disease. SCFAs, such as butyrate, propionate, and acetate, also have important stimulating effects in the intestine, where they nurture epithelial cells, contribute to mucin production, and participate in permeability regulation [3]. Indeed, they also induce the release of hormones and gastrointestinal peptides such as GLP-1, which aid in controlling glycaemia and glucose tolerance, mostly due to its insulinotropic effect $[130,131]$. One experiment showed the production of GLP-1 by a genetically modified Lactococcus 
lactis subsp. Lactis strain, and these novel bacteria demonstrated an insulinotropic effect in in vitro and in vivo experiments [128]. Similarly, a protein secreted from one A. muciniphila strain has been shown to induce GLP-1 secretion that resulted in improved metabolic condition in HFD mice [132]. Along the same line, Amuc_1100, a protein from the outer membrane of A. muciniphila MucT, improved the intestinal barrier function in the same model and is thought to mediate beneficial effects of the probiotic strain [122].

Inflammation is a common underlying factor in different forms of DM [64], and controlling intestinal and systemic inflammation is another alternative way to control DM. Since microbes and enteral immune cells coexist side by side, there is a very intimate connection between the GM and the immune system. Although mucosa tolerance is highly regulated, intestinal disturbances can drive a proinflammatory response, and today it is widely accepted that such activation can be instigated by PAMPs, such as LPS, above mentioned, and other cell components, such as peptidoglycans, flagellin, surface layer proteins, lipoproteins, or lipopolysaccharides, that are recognised by specific pathogen recognition receptors $[77,133,134]$. Accordingly, some postbiotic compounds likely exert immunomodulatory effects [37]; however, this has been less investigated in DM studies. Microbial-derived particles such as SCFAs could aid in controlling inflammation in DM by acting as immune regulators. Previous probiotic studies have shown that probiotics can drive benefits in diabetes and metabolic alternations by changing SCFA production $[107,135,136]$. The included studies, however, did not examine inflammatory markers, and only two studies, one on supernatants [103] and another on inanimate probiotics [25], evaluated cytokine levels and reported improvements in the inflammatory tone. Consequently, further studies should evaluate the effects of SCFAs and other postbiotic molecules on the immune and inflammatory response and diabetes progression. Lastly, postbiotics such as SCFAs [137] or EPSs [23] can modify the local microenvironment and lead to compositional and functional changes in the GM, which could improve glucose metabolism and control inflammation, thus causing benefits in DM.

In the future, researchers must provide a mechanistic basis for the effects of a given postbiotic, and the clinical benefits will ultimately be shown by well-designed double-blind, randomised, placebo-controlled trials. Human data on postbiotics and DM are lacking, and we identified only one trial on this topic in healthy adults [85]. It is likely that ethnic group [138,139], sex [140], and the time course of DM [141] influence the GM response to postbiotic treatments, and these aspects should be contemplated in human studies. Many of the included studies did not analyse the changes in the GM following the interventions, and this would provide valuable information about the underlying mechanisms. In addition, the long-term effects of postbiotics and whether a chronic exposition must be ensured to preserve their beneficial effects remains to be studied. Probably, this will vary among the different postbiotic compounds.

The lack of adverse events is a clear advantage over classic pharmacological antidiabetic drugs that normally have side effects [142]. Nevertheless, we do not know yet whether postbiotics can provide the same benefits as current antidiabetic strategies or if they could be used in combination with classic antidiabetic drugs. As mentioned above, the identity (up to strain level) of the progenitor microorganisms, as well as the production conditions used for the postbiotic manufacturing, strongly impact postbiotics' properties. This limits the ability to compare different experiments and to generalise the findings. In our review, we found many articles that ignored the strain of the microorganisms used in the experiments, and we invite other research teams working on postbiotics to carry out a detailed characterisation of the microbial strains they are working on. In the same line, the different delivery matrices (yogurt [95], pasta [120], liquid solution [89]), may have a key impact on postbiotics' biological effects.

To date, very little research has focused on the antidiabetic effects of SCFAs, phenolic compounds, vitamins, peptides, or bacteriocins, and therefore there is no information about their effects on DM, and future studies are warranted. Along the same line, we did not detect any investigation on vitamins or phenolic-derived postbiotics. A previous in vitro 
study indicated that tannic acid exerts $\alpha$-glucosidase and $\alpha$-amylase inhibitory effects and could therefore offer health benefits in DM [143]. Regarding the bacteriocins, we found one bio-gel prepared with the bacteriocin nisin as an antimicrobial compound, which was effective in alleviating diabetic food infections along with conventional antibiotic treatment [144]. Finally, although less conventional, faecal material transplants have provoked intense interest [145], and human studies have demonstrated improvements in insulin resistance and in faecal metabolites that were attributed to changes in GM composition and activity [146,147]. Thus, they also offer promising opportunities for DM management.

\section{Conclusions}

To the best of our knowledge, this is the first review attempting to summarise the evidence for postbiotics' effects on DM. Although expertise in this area is still rather limited and there are inconsistencies between the results of the studies, the available literature suggests that this new entity in the -biotics field opens the door to new therapeutic and preventive approaches for DM and other metabolic diseases. The analysed literature focuses on how aspects such as the progenitor microorganism, the matrix, and the fermentation conditions, affect the biological effects of postbiotics in a relevant manner. The lack of adverse events and the interesting outcomes reported in the included studies should encourage further studies on postbiotics for the prevention and alleviation of DM. This new field of research represents a great opportunity for researchers, doctors, biotechnologists, and food technicians to join forces in the use of postbiotics as novel therapeutic candidates for the treatment of diseases such as DM.

Author Contributions: Conceptualisation, M.C.-O. and M.B.; methodology, M.C.-O., M.A., R.U., and M.B.; writing - original draft preparation, M.C.-O. and M.B.; writing-review and editing, M.C.-O., M.A., R.U., I.J.E., and M.B.; supervision, I.J.E. and M.B. All authors have read and agreed to the published version of the manuscript.

Funding: This research received no external funding.

Conflicts of Interest: The authors declare no conflict of interest.

\section{References}

1. Şanlier, N.; Gökcen, B.B.; Sezgin, A.C. Health benefits of fermented foods. Crit. Rev. Food Sci. Nutr. 2019, 59, 506-527. [CrossRef]

2. Kranich, J.; Maslowski, K.M.; Mackay, C.R. Commensal flora and the regulation of inflammatory and autoimmune responses. Semin. Immunol. 2011, 23, 139-145. [CrossRef]

3. Macia, L.; Thorburn, A.N.; Binge, L.C.; Marino, E.; Rogers, K.E.; Maslowski, K.M.; Vieira, A.T.; Kranich, J.; Mackay, C.R. Microbial influences on epithelial integrity and immune function as a basis for inflammatory diseases. Immunol. Rev. 2012, 245, 164-176. [CrossRef]

4. Clarke, G.; Stilling, R.M.; Kennedy, P.J.; Stanton, C.; Cryan, J.F.; Dinan, T.G. Minireview: Gut Microbiota: The Neglected Endocrine Organ. Mol. Endocrinol. 2014, 28, 1221-1238. [CrossRef]

5. Qiu, Q.; Lin, Y.; Ma, Y.; Li, X.; Liang, J.; Chen, Z.; Liu, K.; Huang, Y.; Luo, H.; Huang, R.; et al. Exploring the Emerging Role of the Gut Microbiota and Tumor Microenvironment in Cancer Immunotherapy. Front. Immunol. 2021, 11, 1-15. [CrossRef]

6. Sekirov, I.; Russel, S.L.; Antunes, L.C.M.; Finlay, B.B. Gut Microbiota in Health and Disease. Physiol. Rev. 2010, 90, 859-904. [CrossRef] [PubMed]

7. Tlaskalová-Hogenová, H.; Tpánková, R.; Kozáková, H.; Hudcovic, T.; Vannucci, L.; Tuková, L.; Rossmann, P.; Hrní, T.; Kverka, M.; Zákostelská, Z.; et al. The role of gut microbiota (commensal bacteria) and the mucosal barrier in the pathogenesis of inflammatory and autoimmune diseases and cancer: Contribution of germ-free and gnotobiotic animal models of human diseases. Cell. Mol. Immunol. 2011, 8, 110-120. [CrossRef] [PubMed]

8. Wang, X.; Xu, X.; Xia, Y. Further analysis reveals new gut microbiome markers of type 2 diabetes mellitus. Antonie Van Leeuwenhoek 2017, 110, 445-453. [CrossRef]

9. Chaluvadi, S.; Hotchkiss, A.T.; Yam, K.L. Gut Microbiota: Impact of Probiotics, Prebiotics, Synbiotics, Pharmabiotics, and Postbiotics on Human Health. In Probiotics, Prebiotics, and Synbiotics: Bioactive Foods in Health Promotion; Elsevier Inc.: Hoboken, NJ, USA, 2015; pp. 515-523. ISBN 9780128023716.

10. Vyas, U.; Ranganathan, N. Probiotics, Prebiotics, and Synbiotics: Gut and Beyond. Gastroenterol. Res. Pract. 2012, 11. [CrossRef]

11. Ojeda, P.; Bobe, A.; Dolan, K.; Leone, V.; Martinez, K. Nutritional modulation of gut microbiota-The impact on metabolic disease pathophysiology. J. Nutr. Biochem. 2016, 28, 191-200. [CrossRef] [PubMed] 
12. Bermudez-Brito, M.; Plaza-Díaz, J.; Muñoz-Quezada, S.; Gómez-Llorente, C.; Gil, A. Probiotic mechanisms of action. Ann. Nutr. Metab. 2012, 61, 160-174. [CrossRef]

13. Gibson, G.R.; Hutkins, R.; Sanders, M.E.; Prescott, S.L.; Reimer, R.A.; Salminen, S.J.; Scott, K.; Stanton, C.; Swanson, K.S.; Cani, P.D.; et al. The International Scientific Association for Probiotics and Prebiotics (ISAPP) consensus statement on the definition and scope of prebiotics. Nat. Rev. Gastroenterol. Hepatol. 2017, 14, 491-502. [CrossRef]

14. Suez, J.; Zmora, N.; Segal, E.; Elinav, E. The pros, cons, and many unknowns of probiotics. Nat. Med. 2019, 25, 716-729. [CrossRef]

15. Martín, R.; Langella, P. Emerging health concepts in the probiotics field: Streamlining the definitions. Front. Microbiol. 2019, 10. [CrossRef]

16. Sanders, M.E.; Guarner, F.; Mills, D.; Pot, B.; Rafter, J.; Reid, G.; Ringel, Y. Selected Topics in Probiotics and Prebiotics: Meeting Report for the 2004 International Scientific Association for Probiotics and Prebiotics. Curr. Issues Intestig. Microbiol. 2005, 6, 55-68.

17. Roberfroid, M.; Gibson, G.R.; Hoyles, L.; McCartney, A.L.; Rastall, R.; Rowland, I.; Wolvers, D.; Watzl, B.; Szajewska, H.; Stahl, B.; et al. Prebiotic effects: Metabolic and health benefits. Br. J. Nutr. 2010, 104, 72. [CrossRef] [PubMed]

18. Hill, C.; Guarner, F.; Reid, G.; Gibson, G.R.; Merenstein, D.J.; Pot, B.; Morelli, L.; Canani, R.B.; Flint, H.J.; Salminen, S.; et al. The International Scientific Association for Probiotics and Prebiotics consensus statement on the scope and appropriate use of the term probiotic. Nat. Rev. Gastroenterol. Hepatol. 2014, 11, 506-514. [CrossRef] [PubMed]

19. Tsilingiri, K.; Barbosa, T.; Penna, G.; Caprioli, F.; Sonzogni, A.; Viale, G.; Rescigno, M. Probiotic and postbiotic activity in health and disease: Comparison on a novel polarised ex-vivo organ culture model. Gut 2012, 61, 1007-1015. [CrossRef] [PubMed]

20. Salminen, S.; Collado, M.C.; Endo, A.; Hill, C.; Lebeer, S.; Quigley, E.M.M.; Sanders, M.E.; Shamir, R.; Swann, J.R.; Szajewska, H.; et al. The International Scientific Association of Probiotics and Prebiotics (ISAPP) consensus statement on the definition and scope of postbiotics. Nat. Rev. Endocrinol. 2021. [CrossRef]

21. Cuevas-González, P.F.; Liceaga, A.M.; Aguilar-Toalá, J.E. Postbiotics and paraprobiotics: From concepts to applications. Food Res. Int. 2020, 136. [CrossRef]

22. Maria Carmen, C.; Seppo, S.; Vinderola, G. Chapter 11-Postbiotics: Defining the impact of inactivated microbes and their metabolites on promotion of health. In The Human Microbiome in Early Life; Koren, O., Rautava, S., Eds.; Academic Press: Cambridge, MA, USA, 2021; pp. 257-268. ISBN 9780128180976.

23. Wegh, C.A.M.; Geerlings, S.Y.; Knol, J.; Roeselers, G.; Belzer, C. Postbiotics and Their Potential Applications in Early Life Nutrition and Beyond. Int. J. Mol. Med. 2019, 20, 4673. [CrossRef]

24. Aguilar-Toalá, J.E.; Garcia-Varela, R.; Garcia, H.S.; Mata-Haro, V.; González-Córdova, A.F.; Vallejo-Cordoba, B.; HernándezMendoza, A. Postbiotics: An evolving term within the functional foods field. Trends Food Sci. Technol. 2018, 75, 105-114. [CrossRef]

25. Li, X.; Xu, Q.; Jiang, T.; Fang, S.; Wang, G.; Zhao, J.; Zhang, H.; Chen, W. A comparative study of the antidiabetic effects exerted by live and dead multi-strain probiotics in the type 2 diabetes model of mice. Food Funct. 2016, 7, 4851-4860. [CrossRef] [PubMed]

26. Jin, M.; Lu, Z.; Huang, M.; Wang, Y.; Wang, Y. Effects of Se-enriched polysaccharides produced by Enterobacter cloacae Z0206 on alloxan-induced diabetic mice. Int. J. Biol. Macromol. 2012, 50, 348-352. [CrossRef] [PubMed]

27. Tsilingiri, K.; Rescigno, M. Postbiotics: What else? Benef. Microbes 2013, 4, 101-107. [CrossRef] [PubMed]

28. Taverniti, V.; Guglielmetti, S. The immunomodulatory properties of probiotic microorganisms beyond their viability (ghost probiotics: Proposal of paraprobiotic concept). Genes Nutr. 2011, 6, 261-274. [CrossRef]

29. Wang, S.; Ahmadi, S.; Nagpal, R.; Jain, S.; Mishra, S.P.; Kavanagh, K.; Zhu, X.; Wang, Z.; McClain, D.A.; Kritchevsky, S.B.; et al. Lipoteichoic acid from the cell wall of a heat killed Lactobacillus paracasei D3-5 ameliorates aging-related leaky gut, inflammation and improves physical and cognitive functions: From C. elegans to mice. GeroScience 2020, 42, 333-352. [CrossRef] [PubMed]

30. Toscano, M.; De Grandi, R.; Pastorelli, L.; Vecchi, M.; Drago, L. A consumer's guide for probiotics: 10 golden rules for a correct use. Dig. Liver Dis. 2017, 49, 1177-1184. [CrossRef] [PubMed]

31. Żółkiewicz, J.; Marzec, A.; Ruszczyński, M.; Feleszko, W. Postbiotics-A step beyond pre-and probiotics. Nutrients 2020, 12, 2189. [CrossRef]

32. Nataraj, B.H.; Ali, S.A.; Behare, P.V.; Yadav, H. Postbiotics-parabiotics: The new horizons in microbial biotherapy and functional foods. Microb. Cell Fact. 2020, 19, 1-22. [CrossRef]

33. Patel, A.; Prajapat, J.B. Food and Health Applications of Exopolysaccharides produced by Lactic acid Bacteria. Adv. Dairy Res. 2013, 1, 1-8. [CrossRef]

34. Zacharof, M.P.; Lovitt, R.W. Bacteriocins Produced by Lactic Acid Bacteria A Review Article. Apcbee Procedia 2012, 2, 50-56. [CrossRef]

35. Piqué, N.; Berlanga, M.; Miñana-Galbis, D. Health Benefits of Heat-Killed (Tyndallized ) Probiotics: An Overview. Int. J. Mol. Sci. 2019, 20, 2534. [CrossRef]

36. Patel, S.; Majumder, A.; Goyal, A. Potentials of Exopolysaccharides from Lactic Acid Bacteria. Indian J. Microbiol. $2012,52,3-12$. [CrossRef] [PubMed]

37. de Almada, C.N.; Almada, C.N.; Martinez, R.C.R.; Sant'Ana, A.S. Paraprobiotics: Evidences on their ability to modify biological responses, inactivation methods and perspectives on their application in foods. Trends Food Sci. Technol. 2016, 58, 96-114. [CrossRef] 
38. Almada, C.N.; Almada-Érix, C.N.; Roquetto, A.R.; Santos-Junior, V.A.; Cabral, L.; Noronha, M.F.; Gonçalves, A.E.S.S.; dos Santos, P.; dos Santos, A.; Martinez, J.; et al. Paraprobiotics obtained by six different inactivation processes: Impacts on the biochemical parameters and intestinal microbiota of Wistar male rats. Int. J. Food Sci. Nutr. 2021, 1-14. [CrossRef]

39. Anderson, R.C. Are Postbiotics the Long Sought-After Solution for a Leaky Gut? J. Nutr. 2019, 149, 1873-1874. [CrossRef] [PubMed]

40. Chelakkot, C.; Choi, Y.; Kim, D.K.; Park, H.T.; Ghim, J.; Kwon, Y.; Jeon, J.; Kim, M.S.; Jee, Y.K.; Gho, Y.S.; et al. Akkermansia muciniphila-derived extracellular vesicles influence gut permeability through the regulation of tight junctions. Exp. Mol. Med. 2018, 50, e450. [CrossRef]

41. Plaza-Diaz, J.; Ruiz-Ojeda, F.J.; Gil-Campos, M.; Gil, A. Mechanisms of Action of Probiotics. Adv. Nutr. 2019, 10, S49-S66. [CrossRef]

42. Hayes, M.; Ross, R.P.; Fitzgerald, G.F.; Stanton, C. Putting microbes to work: Diary fermentation, cell factories and bioactive peptides. Part I: Overview. Biotechnol. J. 2007, 2, 426-434. [CrossRef] [PubMed]

43. Peluzio, M.D.C.G.; Martinez, J.A.; Milagro, F.I. Postbiotics: Metabolites and mechanisms involved in microbiota-host interactions. Trends Food Sci. Technol. 2021, 108, 11-26. [CrossRef]

44. Haas-neill, S.; Forsythe, P. A budding relationship: Bacterial extracellular vesicles in the microbiota-Gut-brain axis. Int. J. Mol. Sci. 2020, 21, 8899. [CrossRef] [PubMed]

45. Lee, W.J.; Hase, K. Gut microbiota-generated metabolites in animal health and disease. Nat. Chem. Biol. 2014, 10, 416-424. [CrossRef]

46. Lee, B.H.; Wu, S.C.; Shen, T.L.; Hsu, Y.Y.; Chen, C.H.; Hsu, W.H. The applications of Lactobacillus plantarum-derived extracellular vesicles as a novel natural antibacterial agent for improving quality and safety in tuna fish. Food Chem. 2021, 340, 128104. [CrossRef] [PubMed]

47. Mora-Sánchez, B.; Balcázar, J.L.; Pérez-Sánchez, T. Effect of a novel postbiotic containing lactic acid bacteria on the intestinal microbiota and disease resistance of rainbow trout (Oncorhynchus mykiss). Biotechnol. Lett. 2020, 42, 1957-1962. [CrossRef] [PubMed]

48. Hoffman, J.R.; Hoffman, M.W.; Zelicha, H.; Gepner, Y.; Willoughby, D.S.; Feinstein, U.; Ostfeld, I. The Effect of 2 Weeks of Inactivated Probiotic Bacillus coagulans on Endocrine, Inflammatory, and Performance Responses During Self-Defense Training in Soldiers. J. Strength Cond. Res. 2019, 33, 2330-2337. [CrossRef]

49. Fontana, L.; Bermudez-Brito, M.; Plaza-Diaz, J.; Muñoz-Quesada, S.; Gil, A. Sources, isolation, characterisation and evaluation of probiotics. Br. J. Nutr. 2013, 109, S30-S50. [CrossRef]

50. Evivie, S.E.; Huo, G.-C.; Igene, J.O.; Bian, X. Some current applications, limitations and future perspectives of lactic acid bacteria as probiotics. Food Nutr. Res. 2017, 61, 1318034. [CrossRef]

51. Leroy, F.; De Vuyst, L. Lactic acid bacteria as functional starter cultures for the food fermentation industry. Trends Food Sci. Technol. 2004, 15, 67-78. [CrossRef]

52. Zannini, E.; Waters, D.M.; Coffey, A.; Arendt, E.K. Production, properties, and industrial food application of lactic acid bacteriaderived exopolysaccharides. Appl. Microbiol. Biotechnol. 2016, 100, 1121-1135. [CrossRef]

53. García-Cano, I.; Rocha-Mendoza, D.; Ortega-Anaya, J.; Wang, K.; Kosmerl, E.; Jiménez-Flores, R. Lactic acid bacteria isolated from dairy products as potential producers of lipolytic, proteolytic and antibacterial proteins. Appl. Microbiol. Biotechnol. 2019, 103, 5243-5257. [CrossRef] [PubMed]

54. Thakur, K.; Tomar, S.K.; De, S. Lactic acid bacteria as a cell factory for riboflavin production. Microb. Biotechnol. 2016, 9, 441-451. [CrossRef] [PubMed]

55. Ménard, S.; Candalh, C.; Bambou, J.C.; Terpend, K.; Cerf-Bensussan, N.; Heyman, M. Lactic acid bacteria secrete metabolites retaining anti-inflammatory properties after intestinal transport. Gut 2004, 53, 821-828. [CrossRef] [PubMed]

56. ADA. Classification and Diagnosis of Diabetes: Standards of Medical Care in Diabetes-2020. Diabetes Care 2020, 43, S14-S31. [CrossRef] [PubMed]

57. Glovaci, D.; Fan, W.; Wong, N.D. Epidemiology of Diabetes Mellitus and Cardiovascular Disease. Curr. Cardiol. Rep. 2019, 21. [CrossRef]

58. Zheng, Y.; Ley, S.H.; Hu, F.B. Global aetiology and epidemiology of type 2 diabetes mellitus and its complications. Nat. Rev. Endocrinol. 2018, 14, 88-98. [CrossRef]

59. Tilg, H.; Moschen, A.R. Microbiota and Diabetes: An Evolving Relationship. Gut 2014, 63, 1513-1521. [CrossRef] [PubMed]

60. Cabello-Olmo, M.; Araña, M.; Radichev, I.; Smith, P.; Huarte, E.; Barajas, M. New Insights into Immunotherapy Strategies for Treating Autoimmune Diabetes. Int. J. Mol. Sci. 2019, 20, 4789. [CrossRef]

61. Villanueva-Millan, M.J.; Perez-Matute, P.; Oteo, J.A. Gut microbiota: A key player in health and disease. A review focused on obesity. J. Physiol. Biochem. 2015, 71, 509-525. [CrossRef]

62. Magno, C.; Bertelli, S.; De Castro, R.; De Souza, G.T.; Rossato, C.; Carlos, F.; Anete, M.; Valente, S.; Vitor, J.; Rettore, P.; et al. Intestinal Microbiota as Modulators of the Immune System and Neuroimmune System: Impact on the Host Health and Homeostasis. J. Immunol. Res. 2015, 2015, 1-15. [CrossRef]

63. Round, J.L.; Mazmanian, S.K. The gut microbiome shapes intestinal immune responses during health and disease. Nat. Rev. Immunol. 2009, 9, 313-323. [CrossRef] [PubMed] 
64. Tan, S.Y.; Wong, J.L.M.; Sim, Y.J.; Wong, S.S.; Elhassan, S.A.M.; Tan, S.H.; Lim, G.P.L.; Tay, N.W.R.; Annan, N.C.; Bhattamisra, S.K.; et al. Type 1 and 2 diabetes mellitus: A review on current treatment approach and gene therapy as potential intervention. Diabetes Metab. Syndr. Clin. Res. Rev. 2019, 13, 364-372. [CrossRef] [PubMed]

65. Blandino, G.; Inturri, R.; Lazzara, F.; Di Rosa, M.; Malaguarnera, L. Impact of gut microbiota on diabetes mellitus. Diabetes Metab. 2016, 42, 303-315. [CrossRef] [PubMed]

66. Khan, M.T.; Nieuwdorp, M.; Bäckhed, F. Microbial modulation of insulin sensitivity. Cell Metab. 2014, 20, 753-760. [CrossRef] [PubMed]

67. Delzenne, N.M.; Cani, P.D.; Everard, A.; Neyrinck, A.M.; Bindels, L.B. Gut microorganisms as promising targets for the management of type 2 diabetes. Diabetologia 2015, 58, 2206-2217. [CrossRef]

68. Ejtahed, H.S.; Hoseini-Tavassol, Z.; Khatami, S.; Zangeneh, M.; Behrouzi, A.; Ahmadi Badi, S.; Moshiri, A.; Hasani-Ranjbar, S.; Soroush, A.R.; Vaziri, F.; et al. Main gut bacterial composition differs between patients with type 1 and type 2 diabetes and non-diabetic adults. J. Diabetes Metab. Disord. 2020, 19, 265-271. [CrossRef]

69. Adachi, K.; Sugiyama, T.; Yamaguchi, Y.; Tamura, Y.; Izawa, S.; Hijikata, Y.; Ebi, M.; Funaki, Y.; Ogasawara, N.; Goto, C.; et al. Gut microbiota disorders cause type 2 diabetes mellitus and homeostatic disturbances in gut related metabolism in Japanese subjects. J. Clin. Biochem. Nutr. 2019, 64, 231-238. [CrossRef]

70. Piper, M.S.; Saad, R.J. Diabetes Mellitus and the Colon. Curr. Treat. Options Gastroenterol. 2017, 15, 460-474. [CrossRef] [PubMed]

71. Vaarala, O; Atkinson, M.A.; Neu, J. The "Perfect Storm" for Type 1 Diabetes: The Complex Interplay Between Intestinal Microbiota, Gut Permeability, and Mucosal Immunity. Diabetes 2008, 57, 2555-2562. [CrossRef]

72. Gurung, M.; Li, Z.; You, H.; Rodrigues, R.; Jump, D.B.; Morgun, A.; Shulzhenko, N. Role of gut microbiota in type 2 diabetes pathophysiology. EBioMedicine 2020, 51, 102590. [CrossRef] [PubMed]

73. Cani, P.D.; Amar, J.; Iglesias, M.A.; Poggi, M.; Knauf, C.; Bastelica, D.; Neyrinck, A.M.; Fava, F.; Tuohy, K.M.; Chabo, C.; et al. Metabolic Endotoxemia Initiates Obesity and Insulin Resistance. Diabetes 2007, 56, 1761-1772. [CrossRef]

74. Sato, J.; Kanazawa, A.; Watada, H. Type 2 diabetes and bacteremia. Ann. Nutr. Metab. 2017, 71, 17-22. [CrossRef]

75. He, C.; Shan, Y.; Song, W. Targeting gut microbiota as a possible therapy for diabetes. Nutr. Res. 2015, 35, 361-367. [CrossRef]

76. Kootte, R.S.; Vrieze, A.; Holleman, F.; Dallinga-Thie, G.M.; Zoetendal, E.G.; de Vos, W.M.; Groen, A.K.; Hoekstra, J.B.L.; Stroes, E.S.; Nieuwdorp, M. The therapeutic potential of manipulating gut microbiota in obesity and type 2 diabetes mellitus. Diabetes Obes. Metab. 2012, 14, 112-120. [CrossRef]

77. Hampe, C.S.; Roth, C.L. Probiotic strains and mechanistic insights for the treatment of type 2 diabetes. Endocrine 2017, 58, 207-227. [CrossRef]

78. Sato, J.; Kanazawa, A.; Azuma, K.; Ikeda, F.; Goto, H.; Komiya, K.; Kanno, R.; Tamura, Y.; Asahara, T.; Takahashi, T.; et al. Probiotic reduces bacterial translocation in type 2 diabetes mellitus: A randomised controlled study. Sci. Rep. 2017, 7, 12115. [CrossRef]

79. Hansen, C.H.F.; Larsen, C.S.; Petersson, H.O.; Zachariassen, L.F.; Vegge, A.; Lauridsen, C.; Kot, W.; Krych, Ł.; Nielsen, D.S.; Hansen, A.K. Targeting gut microbiota and barrier function with prebiotics to alleviate autoimmune manifestations in NOD mice. Diabetologia 2019, 62, 1689-1700. [CrossRef]

80. Gille, D.; Schmid, A.; Walther, B.; Vergères, G. Fermented Food and Non-Communicable Chronic Diseases: A Review. Nutrients 2018, 10, 448. [CrossRef] [PubMed]

81. Cabello-Olmo, M.; Oneca, M.; Torre, P.; Sainz, N.; Moreno-aliaga, M.J.; Guruceaga, E.; Díaz, J.V.; Encio, I.J.; Barajas, M.; Araña, M. A Fermented Food Product Containing Lactic Acid Bacteria Protects ZDF Rats from the Development of Type 2 Diabetes. Nutrients 2019, 11, 2530. [CrossRef] [PubMed]

82. Sivamaruthi, B.S.; Kesika, P.; Prasanth, M.I.; Chaiyasut, C. A Mini Review on Antidiabetic Properties of Fermented Foods. Nutrients 2018, 10, 1973. [CrossRef] [PubMed]

83. Dahech, I.; Belghith, K.S.; Hamden, K.; Feki, A.; Belghith, H.; Mejdoub, H. Antidiabetic activity of levan polysaccharide in alloxan-induced diabetic rats. Int. J. Biol. Macromol. 2011, 49, 742-746. [CrossRef]

84. Yeap, S.K.; Mohd Ali, N.; Mohd Yusof, H.; Alitheen, N.B.; Beh, B.K.; Ho, W.Y.; Koh, S.P.; Long, K. Antihyperglycemic effects of fermented and nonfermented mung bean extracts on alloxan-induced-diabetic mice. J. Biomed. Biotechnol. 2012, 2012. [CrossRef] [PubMed]

85. Barros, C.P.; Grom, L.C.; Guimarães, J.T.; Balthazar, C.F.; Rocha, R.S.; Silva, R.; Almada, C.N.; Pimentel, T.C.; Venâncio, E.L.; Collopy Junior, I.; et al. Paraprobiotic obtained by ohmic heating added in whey-grape juice drink is effective to control postprandial glycemia in healthy adults. Food Res. Int. 2021, 140. [CrossRef] [PubMed]

86. Zeidan, A.A.; Poulsen, V.K.; Janzen, T.; Buldo, P.; Derkx, P.M.F.; Øregaard, G.; Neves, A.R. Polysaccharide production by lactic acid bacteria: From genes to industrial applications. FEMS Microbiol. Rev. 2017, 41, S168-S200. [CrossRef] [PubMed]

87. Gowd, V.; Baoa, T.; Wangc, L.; Huangc, Y.; Chenc, S.; Zhenga, X.; Cuib, S.; Chena, W. Antioxidant-and-antidiabetic-activity-ofblackberry-after-gastrointestinal-digestion-and-human-gut-microbiota-fermentationFood-Chemistry.pdf. Food Chem. 2018, 269, 618-627. [CrossRef] [PubMed]

88. Melo, F.C.B.C.D.; Zaia, C.T.B.V.; Celligoi, M.A.P.C. Levan from Bacillus Subtilis Natto: Its Effects in Normal and in StreptozotocinDiabetic Rats. Braz. J. Microbiol. 2012, 43, 1613-1619. [CrossRef]

89. Ghoneim, M.A.M.; Hassan, A.I.; Mahmoud, M.G.; Asker, M.S. Effect of polysaccharide from Bacillus subtilis sp. on cardiovascular diseases and atherogenic indices in diabetic rats. BMC Complement. Altern. Med. 2016, 16, 112. [CrossRef] 
90. Huang, Z.; Lin, F.; Zhu, X.; Zhang, C.; Jiang, M.; Lu, Z. An exopolysaccharide from Lactobacillus plantarum H31 in pickled cabbage inhibits pancreas $\alpha$-amylase and regulating metabolic markers in HepG2 cells by AMPK/PI3K/Akt pathway. Int. J. Biol. Macromol. 2020, 143, 775-784. [CrossRef]

91. Ding, X.; Zhang, J.; Jiang, P.; Xu, X.; Liu, Z. Structural features and hypoglycaemie activity of an exopolysaccharide produced by Sorangium cellulosum. Lett. Appl. Microbiol. 2004, 38, 223-228. [CrossRef]

92. Patterson, E.E.; Ryan, P.M.; Cryan, J.F.; Dinan, T.G.; Paul Ross, R.; Fitzgerald, G.F.; Stanton, C.E. Gut microbiota, obesity and diabetes. Postgrad. Med. J. 2016, 92, 286-300. [CrossRef]

93. Abdelazez, A.; Abdelmotaal, H.; Evivie, S.E.; Melak, S.; Jia, F.F.; Khoso, M.H.; Zhu, Z.T.; Zhang, L.J.; Sami, R.; Meng, X.C. Screening potential probiotic characteristics of lactobacillus brevis strains in vitro and intervention effect on type i diabetes in vivo. Biomed. Res. Int. 2018, 2018. [CrossRef]

94. Marques, T.M.; Patterson, E.; Wall, R.; O’Sullivan, O.; Fitzgerald, G.F.; Cotter, P.D.; Dinan, T.G.; Cryan, J.F.; Ross, R.P.; Stanton, C. Influence of GABA and GABA-producing Lactobacillus brevis DPC 6108 on the development of diabetes in a streptozotocin rat model. Benef. Microbes 2016, 7, 409-420. [CrossRef] [PubMed]

95. Li, X.; Chen, L.; Zhu, X.; Lu, Z.; Lu, Y. Effect of $\gamma$-aminobutyric acid-rich yogurt on insulin sensitivity in a mouse model of type 2 diabetes mellitus. J. Dairy Sci. 2020, 103, 7719-7729. [CrossRef] [PubMed]

96. Tian, J.; Dang, H.N.; Yong, J.; Chui, W.S.; Dizon, M.P.G.; Yaw, C.K.Y.; Kaufman, D.L. Oral treatment with $\gamma$-aminobutyric acid improves glucose tolerance and insulin sensitivity by inhibiting inflammation in high fat diet-fed mice. PLoS ONE 2011, 6, e25338. [CrossRef]

97. Soltani, N.; Qiu, H.; Aleksic, M.; Glinka, Y.; Zhao, F.; Liu, R.; Li, Y.; Zhang, N.; Chakrabarti, R.; Ng, T.; et al. GABA exerts protective and regenerative effects on islet beta cells and reverses diabetes. Proc. Natl. Acad. Sci. USA 2011, 108, 11692-11697. [CrossRef] [PubMed]

98. Taneera, J.; Jin, Z.; Jin, Y.; Muhammed, S.J.; Zhang, E.; Lang, S.; Salehi, A.; Korsgren, O.; Renström, E.; Groop, L.; et al. $\gamma-$ Aminobutyric acid (GABA) signalling in human pancreatic islets is altered in type 2 diabetes. Diabetologia 2012, 55, 1985-1994. [CrossRef] [PubMed]

99. Chronopoulos, A.; Kalluri, R. Emerging role of bacterial extracellular vesicles in cancer. Oncogene 2020, 39, 6951-6960. [CrossRef] [PubMed]

100. Lakhter, A.J.; Sims, E.K. Minireview: Emerging roles for extracellular vesicles in diabetes and related metabolic disorders. Mol. Endocrinol. 2015, 29, 1535-1548. [CrossRef] [PubMed]

101. Xiao, Y.; Zheng, L.; Zou, X.; Wang, J.; Zhong, J.; Zhong, T. Extracellular vesicles in type 2 diabetes mellitus: Key roles in pathogenesis, complications, and therapy. J. Extracell. Vesicles 2019, 8, 1625677. [CrossRef]

102. Lim, K.H.; Han, J.H.; Lee, J.Y.; Park, Y.S.; Cho, Y.S.; Kang, K.D.; Yuk, W.J.; Hwang, K.Y.; Seong, S.I.; Kim, B.; et al. Assessment of antidiabetogenic potential of fermented soybean extracts in streptozotocin-induced diabetic rat. Food Chem. Toxicol. 2012, 50, 3941-3948. [CrossRef]

103. Liu, Q.; Liu, Y.; Li, F.; Gu, Z.; Liu, M.; Shao, T.; Zhang, L.; Zhou, G.; Pan, C.; He, L.; et al. Probiotic culture supernatant improves metabolic function through FGF21-adiponectin pathway in mice. J. Nutr. Biochem. 2020, 75, 108256. [CrossRef] [PubMed]

104. Zouari, R.; Ben Abdallah-Kolsi, R.; Hamden, K.; El Feki, A.; Chaabouni, K.; Makni-Ayadi, F.; Sallemi, F.; Ellouze-Chaabouni, S.; Ghribi-Aydi, D. Assessment of the antidiabetic and antilipidemic properties of bacillus subtilis spb1 biosurfactant in alloxaninduced diabetic rats. Biopolymers 2015, 104, 764-774. [CrossRef]

105. Zouari, R.; Hamden, K.; El Feki, A.; Chaabouni, K.; Makni-Ayadi, F.; Sallemi, F.; Ellouze-Chaabouni, S.; Ghribi-Aydi, D. Evaluation of Bacillus subtilis SPB1 biosurfactant effects on hyperglycemia, angiotensin I-converting enzyme (ACE) activity and kidney function in rats fed on high-fat-high-fructose diet. Arch. Physiol. Biochem. 2017, 123, 112-120. [CrossRef] [PubMed]

106. Hossain, U.; Das, A.K.; Ghosh, S.; Sil, P.C. An overview on the role of bioactive $\alpha$-glucosidase inhibitors in ameliorating diabetic complications. Food Chem. Toxicol. 2020, 145, 111738. [CrossRef]

107. Li, X.; Wang, N.; Yin, B.; Fang, D.; Jiang, T.; Fang, S.; Zhao, J.; Zhang, H.; Wang, G.; Chen, W. Effects of Lactobacillus plantarum CCFM0236 on hyperglycaemia and insulin resistance in high-fat and streptozotocin-induced type 2 diabetic mice. J. Appl. Microbiol. 2016, 121, 1727-1736. [CrossRef] [PubMed]

108. Koh, W.Y.; Utra, U.; Ahmad, R.; Rather, I.A.; Park, Y.H. Evaluation of probiotic potential and anti-hyperglycemic properties of a novel Lactobacillus strain isolated from water kefir grains. Food Sci. Biotechnol. 2018, 27, 1369-1376. [CrossRef] [PubMed]

109. Yan, F.; Li, N.; Yue, Y.; Wang, C.; Zhao, L.; Evivie, S.E.; Li, B.; Huo, G. Screening for Potential Novel Probiotics With Dipeptidyl Peptidase IV-Inhibiting Activity for Type 2 Diabetes Attenuation in vitro and in vivo. Front. Microbiol. 2020, 10. [CrossRef] [PubMed]

110. Mulvihill, E.E. Dipeptidyl peptidase inhibitor therapy in type 2 diabetes: Control of the incretin axis and regulation of postprandial glucose and lipid metabolism. Peptides 2018, 100, 158-164. [CrossRef] [PubMed]

111. Twigg, M.S.; Baccile, N.; Banat, I.M.; Déziel, E.; Marchant, R.; Roelants, S.; Van Bogaert, I.N.A. Microbial biosurfactant research: Time to improve the rigour in the reporting of synthesis, functional characterization and process development. Microb. Biotechnol. 2021, 14, 147-170. [CrossRef]

112. Adetunji, A.I.; Olaniran, A.O. Production and potential biotechnological applications of microbial surfactants: An overview. Saudi J. Biol. Sci. 2021, 28, 669-679. [CrossRef] 
113. Cavallari, J.F.; Fullerton, M.D.; Duggan, B.M.; Foley, K.P.; Denou, E.; Smith, B.K.; Desjardins, E.M.; Henriksbo, B.D.; Kim, K.J.; Tuinema, B.R.; et al. Muramyl Dipeptide-Based Postbiotics Mitigate Obesity-Induced Insulin Resistance via IRF4. Cell Metab. 2017, 25, 1063-1074.e3. [CrossRef]

114. Shahmirzadi, F.E.; Ghavamzadeh, S.; Zamani, T. The Effect of Conjugated Linoleic Acid Supplementation on Body Composition, Serum Insulin and Leptin in Obese Adults. Arch. Iran. Med. 2019, 22, 255-261.

115. Saha, S.S.; Ghosh, M. Antioxidant and anti-inflammatory effect of conjugated linolenic acid isomers against streptozotocininduced diabetes. Br. J. Nutr. 2012, 108, 974-983. [CrossRef]

116. Gao, Z.; Yin, J.; Zhang, J.; Ward, R.E.; Martin, R.J.; Lefevre, M.; Cefalu, W.T.; Ye, J. Butyrate Improves Insulin Sensitivity and Increases Energy Expenditure in Mice. Diabetes 2009, 58, 1509-1517. [CrossRef]

117. Matheus, V.; Monteiro, L.; Oliveira, R.; Maschio, D.; Collares-Buzato, C. Butyrate reduces high-fat diet-induced metabolic alterations, hepatic steatosis and pancreatic beta cell and intestinal barrier dysfunctions in prediabetic mice. Exp. Biol. Med. 2017, 242, 1214-1226. [CrossRef] [PubMed]

118. Traisaeng, S.; Batsukh, A.; Chuang, T.H.; Herr, D.R.; Huang, Y.F.; Chimeddorj, B.; Huang, C.M. Leuconostoc mesenteroides fermentation produces butyric acid and mediates Ffar2 to regulate blood glucose and insulin in type 1 diabetic mice. Sci. Rep. 2020, 10, 1-10. [CrossRef]

119. Barros, C.P.; Guimarães, J.T.; Esmerino, E.A.; Duarte, M.C.K.; Silva, M.C.; Silva, R.; Ferreira, B.M.; Sant'Ana, A.S.; Freitas, M.Q.; Cruz, A.G. Paraprobiotics and postbiotics: Concepts and potential applications in dairy products. Curr. Opin. Food Sci. 2020, 32, 1-8. [CrossRef]

120. Almada, C.N.; Almada-Érix, C.N.; Costa, W.K.A.; Silva, J.; Cabral, L.; Noronha, M.F.; Gonçalves, A.E.S.S.; dos Santos, A.; Lollo, P.C.; Magnani, M.; et al. Wheat-durum pasta added of inactivated Bifidobacterium animalis decreases glucose and total cholesterol levels and modulates gut microbiota in healthy rats. Int. J. Food Sci. Nutr. 2021, 1-13. [CrossRef]

121. Ben Othman, M.; Sakamoto, K. Effect of inactivated Bifidobacterium longum intake on obese diabetes model mice (TSOD). Food Res. Int. 2020, 129. [CrossRef] [PubMed]

122. Plovier, H.; Everard, A.; Druart, C.; Depommier, C.; Van Hul, M.; Geurts, L.; Chilloux, J.; Ottman, N.; Duparc, T.; Lichtenstein, L.; et al. A purified membrane protein from Akkermansia muciniphila or the pasteurized bacterium improves metabolism in obese and diabetic mice. Nat. Med. 2017, 23, 107-113. [CrossRef]

123. Depommier, C.; Everard, A.; Druart, C.; Plovier, H.; Van Hul, M.; Vieira-Silva, S.; Falony, G.; Raes, J.; Maiter, D.; Delzenne, N.M.; et al. Supplementation with Akkermansia muciniphila in overweight and obese human volunteers: A proof-of-concept exploratory study. Nat. Med. 2019, 25, 1096-1103. [CrossRef]

124. Humblot, C.; Turpin, W.; Chevalier, F.; Picq, C.; Rochette, I.; Guyot, J.P. Determination of expression and activity of genes involved in starch metabolism in Lactobacillus plantarum A6 during fermentation of a cereal-based gruel. Int. J. Food Microbiol. 2014, 185, 103-111. [CrossRef]

125. Feng, L.; Xie, Y.; Peng, C.; Liu, Y.; Wang, H. A novel antidiabetic food produced via solid-state fermentation of Tartary buckwheat by L. plantarum TK9 and L. paracasei TK1501. Food Technol. Biotechnol. 2018, 56, 373-380. [CrossRef] [PubMed]

126. Shigemori, S.; Oshiro, K.; Wang, P.; Yamamoto, Y.; Wang, Y.; Sato, T.; Uyeno, Y.; Shimosato, T. Generation of Dipeptidyl Peptidase-IV-Inhibiting Peptides from $\beta$-Lactoglobulin Secreted by Lactococcus lactis. Biomed. Res. Int. 2014, 2014. [CrossRef] [PubMed]

127. Chen, Z.; Guo, L.; Zhang, Y.; Walzem, R.L.; Pendergast, J.S.; Printz, R.L.; Morris, L.C.; Matafonova, E.; Stien, X.; Kang, L.; et al. Incorporation of therapeutically modified bacteria into gut microbiota inhibits obesity. J. Clin. Investig. 2014, 124, 3391-3406. [CrossRef] [PubMed]

128. Agarwal, P.; Khatri, P.; Billack, B.; Low, W.-K.; Shao, J. Oral Delivery of Glucagon Like Peptide-1 by a Recombinant Lactococcus lactis. Pharm. Res. 2014, 31, 3404-3414. [CrossRef] [PubMed]

129. Tomaro-Duchesneau, C.; LeValley, S.L.; Roeth, D.; Sun, L.; Horrigan, F.T.; Kalkum, M.; Hyser, J.M.; Britton, R.A. Discovery of a bacterial peptide as a modulator of GLP-1 and metabolic disease. Sci. Rep. 2020, 10, 1-12. [CrossRef]

130. Doyle, M.E.; Egan, J.M. Mechanisms of action of glucagon-like peptide 1 in the pancreas. Pharmacol. Ther. 2007, 113, 546-593. [CrossRef] [PubMed]

131. Wichmann, A.; Allahyar, A.; Greiner, T.U.; Plovier, H.; Gunnel, O.; Larsson, T.; Drucker, D.J.; Delzenne, N.M.; Cani, P.D.; Ba, F. Microbial Modulation of Energy Availability in the Colon Regulates Intestinal Transit. Cell Host Microbe 2013, 14, 582-590. [CrossRef]

132. Yoon, H.S.; Cho, C.H.; Yun, M.S.; Jang, S.J.; You, H.J.; Kim, J.H.; Han, D.; Cha, K.H.; Moon, S.H.; Lee, K.; et al. Akkermansia muciniphila secretes a glucagon-like peptide-1-inducing protein that improves glucose homeostasis and ameliorates metabolic disease in mice. Nat. Microbiol. 2021, 6, 563-573. [CrossRef]

133. Tlaskalová-Hogenová, H.; Tučková, L.; Lodinová-Žádniková, R.; Štěpánková, R.; Cukrowska, B.; Funda, D.P.; Střiž, I.; Kozáková, H.; Trebichavský, I.; Sokol, D.; et al. Mucosal immunity: Its role in defense and allergy. Int. Arch. Allergy Immunol. 2002, 128, 77-89. [CrossRef] [PubMed]

134. Cani, P.D. Human gut microbiome: Hopes, threats and promises. Gut 2018, 67, 1-10. [CrossRef] [PubMed]

135. Aoki, R.; Kamikado, K.; Suda, W.; Takii, H.; Mikami, Y.; Suganuma, N.; Hattori, M.; Koga, Y. A proliferative probiotic Bifidobacterium strain in the gut ameliorates progression of metabolic disorders via microbiota modulation and acetate elevation. Sci. Rep. 2017, 7, 1-10. [CrossRef] 
136. Li, C.; Ding, Q.; Nie, S.P.; Zhang, Y.S.; Xiong, T.; Xie, M.Y. Carrot Juice Fermented with Lactobacillus plantarum NCU116 Ameliorates. J. Agric. Food Chem. 2014, 62, 11884-11891. [CrossRef] [PubMed]

137. Dai, S.; Pan, M.; El-Nezami, H.S.; Wan, J.M.F.; Wang, M.F.; Habimana, O.; Lee, J.C.Y.; Louie, J.C.Y.; Shah, N.P. Effects of Lactic Acid Bacteria-Fermented Soymilk on Isoflavone Metabolites and Short-Chain Fatty Acids Excretion and Their Modulating Effects on Gut Microbiota. J. Food Sci. 2019, 84, 1854-1863. [CrossRef]

138. Alvarez-Silva, C.; Kashani, A.; Hansen, T.H.; Pinna, N.K.; Anjana, R.M.; Dutta, A.; Saxena, S.; Støy, J.; Kampmann, U.; Nielsen, T.; et al. Trans-ethnic gut microbiota signatures of type 2 diabetes in Denmark and India. Genome Med. 2021, 13, 1-13. [CrossRef]

139. Pinna, N.K.; Anjana, R.M.; Saxena, S.; Dutta, A.; Gnanaprakash, V.; Rameshkumar, G.; Aswath, S.; Raghavan, S.; Rani, C.S.S.; Radha, V.; et al. Trans-ethnic gut microbial signatures of prediabetic subjects from India and Denmark. Genome Med. 2021, 13, 1-20. [CrossRef] [PubMed]

140. Bolnick, D.I.; Snowberg, L.K.; Hirsch, P.E.; Lauber, C.L.; Org, E.; Parks, B.; Lusis, A.J.; Knight, R.; Caporaso, J.G.; Svanbäck, R. Individual diet has sex-dependent effects on vertebrate gut microbiota. Nat. Commun. 2014, 5, 1-13. [CrossRef]

141. Zhang, Z.; Tian, T.; Chen, Z.; Liu, L.; Luo, T.; Dai, J. Characteristics of the gut microbiome in patients with prediabetes and type 2 diabetes. PeerJ 2021, 9. [CrossRef]

142. Duarte, A.M.; Guarino, M.P.; Barroso, S.; Gil, M.M. Phytopharmacological strategies in the management of type 2 diabetes mellitus. Foods 2020, 9, 271. [CrossRef]

143. Abdelli, I.; Benariba, N.; Adjdir, S.; Fekhikher, Z.; Daoud, I.; Terki, M.; Benramdane, H.; Ghalem, S. In silico evaluation of phenolic compounds as inhibitors of A-amylase and A-glucosidase. J. Biomol. Struct. Dyn. 2021, 39, 816-822. [CrossRef]

144. Santos, R.; Ruza, D.; Cunha, E.; Tavares, L.; Oliveira, M. Diabetic foot infections: Application of a nisin-biogel to complement the activity of conventional antibiotics and antiseptics against Staphylococcus aureus biofilms. PLoS ONE 2019, 14, e0220000. [CrossRef] [PubMed]

145. Smits, L.P.; Bouter, K.E.C.; De Vos, W.M.; Borody, T.J.; Nieuwdorp, M. Therapeutic potential of fecal microbiota transplantation. Gastroenterology 2013, 145, 946-953. [CrossRef] [PubMed]

146. Kootte, R.S.; Levin, E.; Salojärvi, J.; Smits, L.P.; Hartstra, A.V.; Udayappan, S.D.; Hermes, G.; Bouter, K.E.; Koopen, A.M.; Holst, J.J.; et al. Improvement of Insulin Sensitivity after Lean Donor Feces in Metabolic Syndrome Is Driven by Baseline Intestinal Microbiota Composition. Cell Metab. 2017, 26, 611-619. [CrossRef]

147. Vrieze, A.; Van Nood, E.; Holleman, F.; Salojärvi, J.; Kootte, R.S.; Bartelsman, J.F.W.M.; Dallinga-Thie, G.M.; Ackermans, M.T.; Serlie, M.J.; Oozeer, R.; et al. Transfer of Intestinal Microbiota From Lean Donors Increases Insulin Sensitivity in Individuals With Metabolic Syndrome. Gastroenterology 2012, 143, 913-916. [CrossRef] [PubMed] 